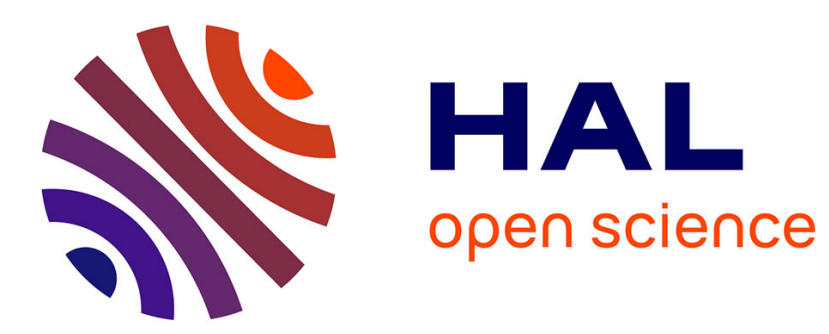

\title{
Vertical Differentiation, Uncertainty, Product R\&D and Policy Instruments in a North-South Duopoly
}

Julien Berthoumieu, Viola Lamani

\section{To cite this version:}

Julien Berthoumieu, Viola Lamani. Vertical Differentiation, Uncertainty, Product R\&D and Policy Instruments in a North-South Duopoly. 2016. hal-01285559

\section{HAL Id: hal-01285559 \\ https://hal.science/hal-01285559}

Preprint submitted on 9 Mar 2016

HAL is a multi-disciplinary open access archive for the deposit and dissemination of scientific research documents, whether they are published or not. The documents may come from teaching and research institutions in France or abroad, or from public or private research centers.
L'archive ouverte pluridisciplinaire HAL, est destinée au dépôt et à la diffusion de documents scientifiques de niveau recherche, publiés ou non, émanant des établissements d'enseignement et de recherche français ou étrangers, des laboratoires publics ou privés. 
Laboratoire d'Analyse et de ReCherche en Économie et Finance Internationales

\section{Vertical Differentiation, Uncertainty, Product R\&D and Policy Instruments in a North-South Duopoly}

Julien Berthoumieu

Viola Lamani

LAREFI Working Paper N²016-02

http://lare-efi.u-bordeaux4.fr

LAREFI

Université de Bordeaux

Bâtiment Recherche Economie $-1^{\text {er }}$ étage

Avenue Léon Duguit - 33608 Pessac 


\section{AUTHORS}

Julien Berthoumieu, Larefi, Université de Bordeaux

Viola Lamani, Larefi, Université de Bordeaux

\section{NOTICES}

LAREFI Working Papers contain preliminary material and research results. They have been peer reviewed. They are circulated in order to stimulate discussion and critical comment; any opinions expressed are only those of the author(s).

Copyright LAREFI. All rights reserved. Sections of this material may be reproduced for personal and not-forprofit use without the express written permission of but with acknowledgment to LAREFI. To reproduce the material contained herein for profit or commercial use requires express written permission. To obtain permission, contact LAREFI at cyril.mesmer@u-bordeaux4.fr. 


\section{Summary}

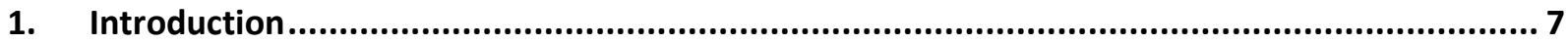

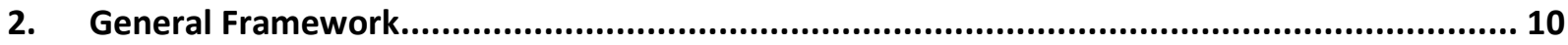

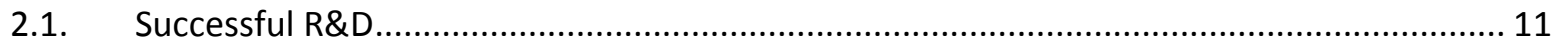

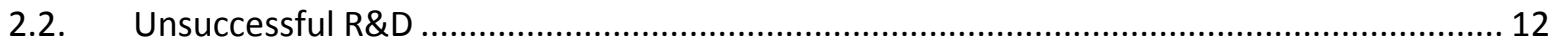

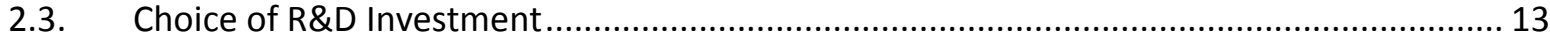

3. Equilibrium with Linear Demand Functions ..................................................................... 13

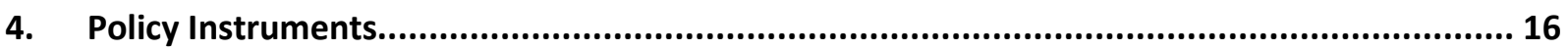

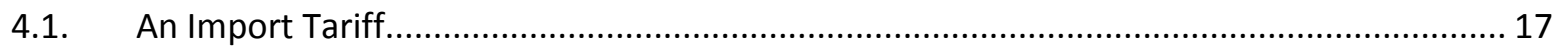

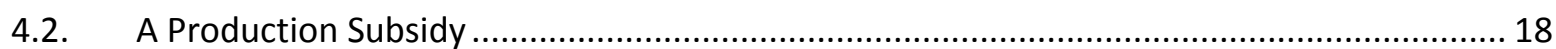

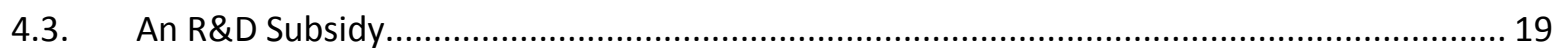

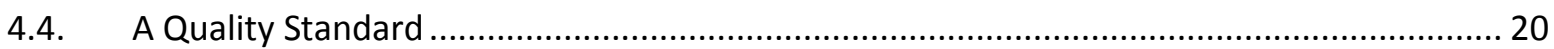

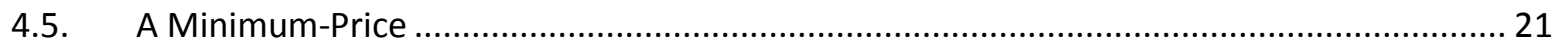

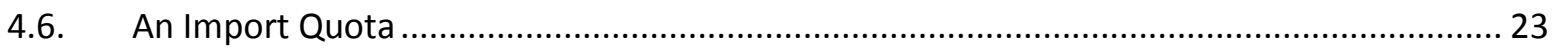

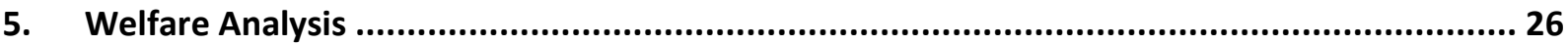

5.1. General Framework under Free Trade …...................................................................... 26

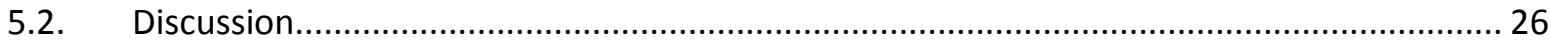

5.3. Optimal Policy Instruments under Numerical Simulations................................................ 28

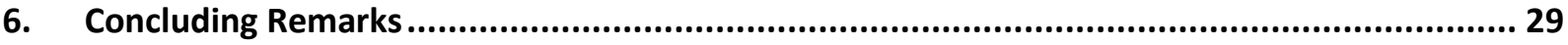

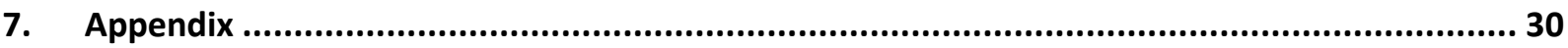

A. Impact of an Import Tariff under General Forms for Demand Functions ................................ 30

B. Impact of "At-The-Border" Policy Instruments on Expected Consumer Surplus ........................30

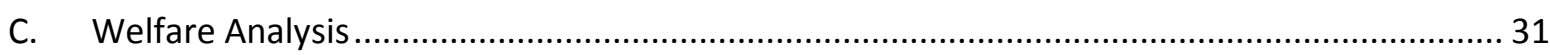




\section{List of Tables}

Table 1 - Economic Impact of Each Policy Instrument

Table 2 - Evolution of the Northern Country's Expected Consumer Surplus with an Import Tariff, a Quality Standard, a Minimum-price and an Import Quota 31

Table 3 - Optimal Policy Instruments and Evolution of the Northern Country's Expected National

Welfare 31 


\section{List of Figures}

Figure 1 - Evolution of the difference in profit $\boldsymbol{\pi} \boldsymbol{d}-\boldsymbol{\pi} \boldsymbol{h}$ when $\boldsymbol{\phi}$ varies

Figure 2 - Evolution of the expected Northern consumer surplus when the R\&D investment varies.. 16

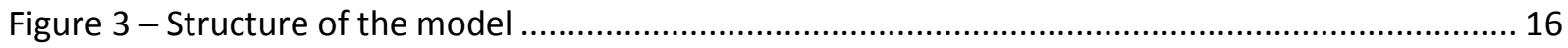

Figure 4 - Evolution of the Northern firm's R\&D Investment When $\boldsymbol{q}$ Varies..................................... 25 


\begin{abstract}
This paper analyzes the impact of several trade policy instruments on product Research and Development (R\&D) investment in a North-South duopoly where a Northern firm competes in prices with a Southern firm on both markets. The Northern firm invests in product R\&D owing to a competitive disadvantage compared to the Southern firm which benefits from a lower labor cost. The outcome of the R\&D activity is uncertain. If successful, vertical differentiation occurs in both markets. The Northern country's government is the only one policy active and may implement the following trade policy instruments: an import tariff, a production subsidy, an R\&D subsidy, a standard of quality, a minimum-price, and an import quota. The results show that the Northern firm's R\&D expenditures increase with each policy instrument except for the import quota. The paper also provides a welfare analysis in order to verify whether or not the Northern government is encouraged to implement these policy instruments.
\end{abstract}

Keywords: Trade Policy Instruments; Product Research and Development; North-South Duopoly; Vertical Differentiation.

JEL Classifications: F13, O30. 


\section{Introduction}

In the aftermath of the global economic crisis when many developed and developing countries have still not fully recovered, decision makers' attention is increasingly drawn to structural reforms needed to raise their countries' competitiveness 1 as one of the main drivers of economic prosperity. Determining and implementing the right policies for improving competitiveness is a challenging issue and has been for years, especially in high-income economies facing a growing competition from lowincome ones. According to the 2014-2015 Global Competitiveness Report Highlights2, economies which have successfully managed to stay the most competitive "are able to develop ... and constantly introduce new and higher value-added products and services into the market." 3 Not surprisingly, the majority of these economies have registered the highest Research and Development (R\&D) expenditures as percentage of GDP.4 Since process and/or product innovation is essential to economic growth, determining whether high-income countries' governments can continue to support their domestic firms' R\&D activities becomes crucial. In light of the foregoing, the objective of this paper is to evaluate the impact of several trade policy instruments on R\&D investment. We also examine the impact of these instruments on firms' profits, consumer surplus and public revenues. We conclude our study by conducting a welfare analysis.

Product R\&D influences features of finished goods such as quality. There is vertical differentiation. Mussa and Rosen (1978) design an important model with product R\&D and product quality. They compare the levels of quality under two market structures: monopoly and competition. The main conclusion is that producers sell less quality goods under monopoly compared to competition. Such a result explains why the cost for consumers under monopoly increases with their taste for quality. Prices are also higher under monopoly. Shaked and Sutton (1982) also study the choice of quality under a theoretical model in which firms set, first, the optimal level of quality, and then, the optimal level of price. Under duopoly, firms select different levels of quality, while they select the same level when the number of firms is greater than two.

The economic literature has already studied similar issues by focusing on cost-reducing/process R\&D. It has been shown empirically that firms invest in both product and process R\&D (Capon et al., 1992; Landau and Rosenberg, 1992). Studies show that firms invest in product R\&D at the beginning of a product's lifecycle, and invest in process R\&D at the end (Utterback and Abernathy, 1975; Klepper, 1996). It explains why firms invest more in product R\&D (Chenavaz, 2011). We, however, focus on product R\&D, which is more important than process R\&D in countries such as Germany, the United States, and Japan according to empirical data (Fritsch and Meschede, 2001; Nagaoka and Walsh, 2009). 5 Product R\&D is particularly higher than process R\&D in high-tech industries like automobile

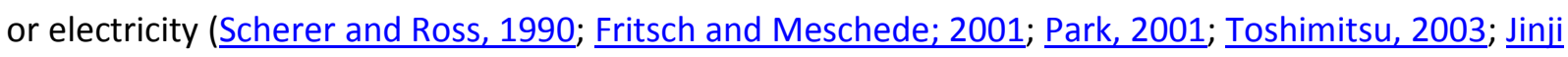
and Toshimitsu, 2013). Nevertheless, there are relatively few studies related to our analysis (Park,

\footnotetext{
${ }^{1}$ Competitiveness (in international trade) may be defined as a measure of a country's advantage or disadvantage in selling its products on international markets (Source: OECD).

${ }^{2}$ Source: World Economic Forum.

${ }^{3}$ The most competitive countries are: Switzerland, Singapore, the United States, Finland, Germany, Japan, Hong Kong, the Netherlands, the United Kingdom and Sweden.

${ }^{4}$ Source: World Bank WDI.

${ }^{5}$ Fritsch and Meschede (2001) note that product R\&D accounts for 61 percent of all R\&D expenditures for German firms. Nagaoka and Walsh (2009) show that process innovations accounted for only 25 percent and 17 percent of all R\&D projects in the US and Japan respectively.
} 
2001; Zhou et al., 2002; Jinji, 2003; Jinji and Toshimitsu, 2006; Jinji and Toshimitsu, 2013; Ishii, 2014). These authors develop theoretical models of international trade with vertically differentiated products. Their main objective is identifying optimal strategic product R\&D policies. The economic literature also studies the case of vertical differentiation under an asymmetric framework between a high-tech firm from a rich country and a low-tech firm from a developing country (Das and Donnenfeld, 1989; Park, 2001; Zhou, Spencer and Vertinsky, 2002; Moraga-Gonzalez and Viaene, 2005; Ishii, 2014).

Park (2001) designs a duopoly with a high- and a low-tech firm. They compete in Bertrand or Cournot fashion on a third market. They produce vertically differentiated products, whose quality is determined endogenously through product R\&D investment. 6 The main result of the paper is that the governments' incentives targeting their domestic firms' R\&D activities depend on the nature of market competition. Under Bertrand competition, the optimal strategic policy is to tax (respectively subsidize) the high-tech's (respectively low-tech's) firm product R\&D. Results are reversed in case of Cournot competition. Furthermore, the author discusses briefly the case when different instruments are combined to serve the high-tech firm's government strategic policy. A combination of an export subsidy and an R\&D tax is demonstrated to be optimal. The model of Zhou, Spencer and Vertinsky (2002) is very similar to Park (2001) in its framework and results regarding unilateral optimal strategic product R\&D policies. They extend the analysis by examining the governments' incentives when there is policy coordination between the two countries. The authors find that when firms compete in prices, the jointly optimal policy is to subsidize (tax) product R\&D activities of the high-quality (low-quality) producing firm. Under Cournot competition on the other hand, the optimal policy is to implement an R\&D tax in both countries. Nevertheless, empirical examples of R\&D taxes are scarce (Audretsch and Yamawaki, 1988; Gabriele, 2002; Impullitti, 2010).

While both of these papers' analysis applies to competition between firms with large asymmetries in R\&D costs, as it is the case for firms from developed and developing countries, Jinii (2003) studies strategic product R\&D policy choices in a third-market trade model in which domestic and foreign firms are identical, facing the same product R\&D costs. In his vertically differentiated duopoly framework, the author shows that governments' optimal strategies involve different subsidy/tax schedules which depend on the mode of competition. This result is qualitatively similar to Park (2001) and Zhou et al. (2002) except for the high-quality exporter's identity which is undetermined. Either firm can produce and export the high-quality good, so that its government will choose to tax or subsidize its product R\&D investment accordingly. Meanwhile, Jinji and Toshimitsu (2006) study strategic product $R \& D$ policies when firms have asymmetric R\&D costs. Their analysis differs from Park (2001) and Zhou et al. (2002) since a small technology gap between firms is assumed. The quality ordering is endogenously determined. The firm with superior technology produces the high-quality good, while its competitor produces the low-quality one. This is achieved by implementing a firmspecific subsidy schedule that depends on the nature of market competition.

Jinii and Toshimitsu (2013) extend previous studies by including a third exporting firm/country in their model. Firms export their entire production to a fourth country. They have different R\&D capabilities, but their R\&D cost functions are identical as long as their products qualities are below their R\&D

\footnotetext{
${ }^{6}$ Park (2001) assumes that the difference in terms of product R\&D costs between firms is large enough so that firms with lower quality improvement costs (high-tech firms) produce and export higher-quality goods compared to low-tech competitors.
} 
capabilities. Contrary to earlier studies, the authors find that the optimal strategic R\&D policy is influenced by the nature of market competition only in the case of the high-quality exporter. Governments of the middle and low-quality exporters would respectively tax and subsidize their domestic firm's R\&D under both price and quantity competition. If firms coordinate, the joint optimal R\&D policies differ depending on the countries' coordination pairs and mode of competition. Finally, Ishii (2014) develops a theoretical third-country trade model of price competition with less stringent demand and cost functions. As opposed to his predecessor, Ishii (2014) finds that the optimal R\&D policy does not necessarily depend only on the mode of competition, given that in certain situations, both governments' optimal policy involves a product R\&D subsidy even when firms compete in Bertrand fashion.

Contrary to the above mentioned studies, which focus primarily on determining the optimal strategic product R\&D policies, we explore the impact of a wider panel of trade policy instruments on product R\&D investment and welfare. These instruments are: an import tariff, a production subsidy, an R\&D subsidy, a minimum quality standard, a minimum-price, and an import quota. We focus on "behindthe-border" policies such as subsidies and "at-the-border" policies such as import tariffs and quotas. Currently, governments use "behind-the-border" policies more frequently for three reasons: (i) they are a means to give domestic firms an advantage over foreign firms; (ii) they escape the notice of the World Trade Organization (WTO) which is more effective in prohibiting instruments representing a direct barrier against international trade flows; (iii) according to the WTO, import tariffs are bound and cannot be increased above a certain level. Evenett (2013) describes the rise in trade policy instruments as "protectionism's quiet return" and mentions that "non-traditional forms of protections still dominate crisis-era protectionism [p. 28]." Traditional forms such as tariffs represent less than 40 percent of the protectionism measures implemented since 2008. Nevertheless, using the example of the automobile industry in 2014, the European Union's ad-valorem import tariff equals 10 percent. 7 Furthermore, developed countries still implement import quotas in the automobile industry. The number of quantitative restrictions in force on automobile vehicles imports in 2015 is 18 in Australia, 6 in Canada, 4 in the European Union, 12 in Japan, 8 in New-Zealand, and 7 in Switzerland. 8 Such high levels may legitimize the fact that we study the impact of an import tariff and of an import quota.

We design a North-South duopoly where firms with asymmetric production costs compete in prices on both markets. We assume that the Northern country's government is the only one policy active. The Northern firm bears higher production costs and has an incentive to invest in product R\&D. The outcome of this investment is uncertain. If successful, the Northern firm produces a higher-quality version of the same good compared to its Southern competitor. If the Northern firms' R\&D outcome is unsuccessful, then no quality improvement is implemented and the goods are horizontally differentiated due to their different cost structure. Our modeling of product R\&D uncertainty is based on Bouët (2001). We believe it yields more realistic results, which is one of the contributions of our paper to the existing literature. Our model involves a three-stage game. First, the Northern firm's government selects the optimal instrument level by anticipating the Northern firm's product R\&D investment and levels of price. Second, the Northern firm decides on the product R\&D expenditures that maximize its expected profit. In the final stage, firms set their levels of price. Our framework

\footnotetext{
${ }^{7}$ Source: MAcMap HS6.

${ }^{8}$ Source WTO.
} 
relates to the automobile industry in which Northern firms invest in product R\&D in order to face a growing competition from Southern firms that benefit from lower production costs.

The main finding of our analysis is that each policy instrument increases the Northern firm's R\&D expenditures except for the import quota. Therefore, a government whose only aim is to enhance non-price competitiveness by encouraging product $R \& D$ investments should implement one of these policy instruments. Nevertheless, the latter may have opposite effects on the expected consumer surplus, public revenues and welfare. We illustrate this result through numerical simulations.

The rest of this paper is organized as follows. Section 2 describes the theoretical model. Section 3 presents an example under linear demand functions. Section 4 analyzes the impact of six different policy instruments on the Northern firms' R\&D investment. Section 5 conducts a welfare analysis and compares the efficiency of the policy instruments. Section 6 concludes.

\section{General Framework}

We develop a theoretical model of international trade with product innovations in a North-South duopoly with a firm from a Northern country and another from a Southern country. Each firm sells one share of its output domestically and exports the other share to the foreign market. The Southern firm has a cheaper labor force compared to its competitor. Assuming that the Northern firm is located in a developed country, while its Southern trade partner is from an emerging country, considering that the latter has lower labor costs is not unrealistic. The Northern firm has an incentive to invest in Research and Development (R\&D) and vertically differentiate its product since the Southern firm benefits from a competitive advantage.

Such a framework relates to an empirical example, for instance the automobile industry. Firms export their finished good to foreign markets. The North-South duopoly works because Northern automobile firms face competition from Southern automobile firms. A significant example is Tata, an Indian firm which sells on its domestic market and exports to Northern markets. The firm operates "in over 175 markets" and has "over 6,600 sales and service touch points". ${ }^{9}$ The European Union represents an important market. Maruti Suzuki is another good example. The competition from Southern automobile firms is growing owing to lower production costs compared to Northern firms. The Indian market symmetrically represents a great opportunity for Northern automobile firms like Renault and Honda. For example, Renault sold 43,384 vehicles between January and April $2015 .{ }^{10}$ It also launched a new car model called "Kwid" for the Indian market on September 2015. Furthermore, the automobile industry is a good example because firms invest in product R\&D.

As we said previously, the economic literature shows that firms invest more in product R\&D than in process R\&D in high-tech industries (Scherer and Ross, 1990; Fritsch and Meschede; 2001; Park, 2001; Toshimitsu, 2003; Jinii and Toshimitsu, 2013). R\&D expenditures are generally higher for Northern firms compared to Southern firms. It explains why the quality of Northern automobile firms' vehicles is generally higher compared to those of Southern automobile firms. But a limit of our model is that we consider a simple case in which the Southern firm does not invest in R\&D at all. In our model, the outcome of the Northern firm's R\&D investment is uncertain. If successful, two different quality levels

\footnotetext{
${ }^{9}$ Source: Tata $69^{\text {th }}$ Annual Report 2013-2014, p. 16.

${ }^{10}$ Source: The Economic Times.
} 
of the same commodity variety are on markets. Goods produced by both firms are similar in terms of quality, otherwise. Consider a probability of R\&D success.

Assumption 1: There is Bertrand competition on each market. Firms select the optimal levels of price.

We denote by $p_{n}\left(p_{s}\right)$ the price set by the Northern firm on the Northern (Southern) market and $x_{n}$ $\left(x_{s}\right)$ the Northern firm's domestic sales (exports). We also denote by $p_{n}^{*}\left(p_{s}^{*}\right)$ the Southern firm's price on the Northern (Southern) market and $y_{n}\left(y_{s}\right)$ the Southern firm's exports (domestic sales). We use the superscript $d$ to denote the case of a successful R\&D (i.e. with vertical differentiation) and the superscript $h$, otherwise. For example, $p_{n}^{d}\left(p_{n}^{h}\right)$ denotes the Northern firm's price when the R\&D outcome is successful (unsuccessful).

Assumption 2: The probability of R\&D success is denoted by $\alpha$ with $0<\alpha<1$. The probability that the R\&D investment fails is $(1-\alpha)$. The probability of success depends on the R\&D investment level denoted by $r: \alpha=\alpha(r)$. It increases with the R\&D level: $\alpha^{\prime}(r)>0$. Nevertheless, the returns are decreasing: $\alpha^{\prime}(r) \leq 0$.

The economic literature has also considered decreasing returns for R\&D expenditures (Spencer and Brander, 1983 ${ }^{11}$; Reitzes, 1991). A product R\&D investment is an investment in knowledge. A good example is labor training. The training focuses on developing the labor to ensure that the quality of the output increases. In this case, decreasing returns mean that the marginal effect of training may decrease over time. This assumption is really important since it influences a broad set of our results, in particular the impact of any policy instrument on the Northern firm's R\&D.

Assumption 3: The total cost of the Northern firm's R\&D investment is $v r$, where $v$ denotes the unit cost of the R\&D investment. The Northern firm faces such a cost regardless of the R\&D outcome.

When no trade policy instruments are implemented, our model involves a two-stage game. First, the Northern firm selects the level of R\&D investment that maximizes its expected profit by anticipating the levels of price. Second, each firm sets the levels of price that maximize its profit. The equilibrium solution is obtained by backward induction from the second stage of price competition. We analyze separately the case when the R\&D outcome is successful, and subsequently when it is unsuccessful.

\subsection{Successful R\&D}

First consider the case of a successful R\&D investment. We use the superscript $d$ for each variable. Goods are vertically differentiated.

Assumption 4: Firms produce vertically differentiated goods. Each country's consumer has a preference for quality denoted by $\theta$ that increases with the degree of differentiation of the good produced by the domestic firm, denoted by $\phi: \theta=\theta(\phi)$. To simplify the demonstration, consider that the preference for quality is the same for each consumer in both the North and the South. Demand for a given good depends therefore on prices and on such a preference for quality: $x_{i}^{d}=x_{i}^{d}\left[p_{i}^{d}, p_{i}^{* d}, \theta(\phi)\right], y_{i}^{d}=y_{i}^{d}\left[p_{i}^{d}, p_{i}^{* d}, \theta(\phi)\right], \forall i=\{n, s\}$. The demand for the Northern

\footnotetext{
${ }^{11}$ For example, Spencer and Brander (1983) consider cost-reducing R\&D expenditures. They assume that the second derivative of total production costs with respect to R\&D expenditures is negative.
} 
(Southern) firm's product increases (decreases) with the degree of differentiation: $\partial x_{i}^{d} / \partial \phi>0$, $\partial y_{i}^{d} / \partial \phi<0$.

We denote by $C^{d}\left(C^{* d}\right)$ the Northern (Southern) firm's total production cost. Consider linear total production costs functions such as marginal costs are constant. We denote by $c^{d}\left(c^{*}\right)$ the Northern (Southern) firm's marginal cost. The level of $c^{*}$ does not depend on the R\&D outcome.

Assumption 5: The Northern firm's production cost depends on the degree of vertical differentiation. Producing a high quality good is costly: $\partial C^{d} / \partial \phi>0$. The marginal cost also depends on the degree of vertical differentiation and increases with it: $c^{d}=c^{d}(\phi), \partial c^{d} / \partial \phi>0$.

The economic literature considers that quality improvement influences either variable costs or fixed costs (Maskus et al., 2013; Cheng, 2014). Here we consider an endogenous variable cost for the Northern firm. The cost of the last unit of output increases with its level of quality. The total cost functions are the following:

$C^{d}=c^{d}(\phi)\left\{x_{n}^{d}\left[p_{n}^{d}, p_{n}^{* d}, \theta(\phi)\right]+x_{s}^{d}\left[p_{s}^{d}, p_{s}^{* d}, \theta(\phi)\right]\right\}+g x_{s}^{d}\left[p_{s}^{d}, p_{s}^{* d}, \theta(\phi)\right]+F$

$C^{* d}=c^{*}\left\{y_{n}^{d}\left[p_{n}^{d}, p_{n}^{* d}, \theta(\phi)\right]+y_{s}^{d}\left[p_{s}^{d}, p_{s}^{* d}, \theta(\phi)\right]\right\}+g^{*} y_{n}^{d}\left[p_{n}^{d}, p_{n}^{* d}, \theta(\phi)\right]+F^{*}$

The parameters $g$ and $g^{*}$ denote unit transport costs, and $F$ and $F^{*}$ denote fixed costs. Introducing transport costs is more credible for this model. Exports involve higher costs compared to domestic sales. Such a transport cost depends on the geographic distance between countries. We introduce fixed costs in order to integrate increasing returns.

$\Pi^{d}\left(\Pi^{* d}\right)$ denotes the Northern (Southern) firm's profit with a successful R\&D i.e. with vertical differentiation. We have: ${ }^{12}$

$$
\begin{aligned}
& \Pi^{d}=p_{n}^{d} x_{n}^{d}+p_{s}^{d} x_{s}^{d}-c^{d}\left(x_{n}^{d}+x_{s}^{d}\right)-g x_{s}^{d}-F-v r \\
& \Pi^{* d}=p_{n}^{* d} y_{n}^{d}+p_{s}^{* d} y_{s}^{d}-c^{*}\left(y_{n}^{d}+y_{s}^{d}\right)-g^{*} y_{n}^{d}-F^{*}
\end{aligned}
$$

\subsection{Unsuccessful R\&D}

Consider now the case in which the R\&D is unsuccessful. We use the superscript $h$ for each variable. We denote by $C^{h}\left(C^{* h}\right)$ the Northern (Southern) firm's total production cost.

The parameter $c^{h}$ denotes the Northern firm's constant marginal cost. According to Assumption 5, we have: $c^{d}(\phi)>c^{h}$. Consider specific linear functions for total production costs:

$$
\begin{aligned}
& C^{h}=c^{h}\left[x_{n}^{h}\left(p_{n}^{h}, p_{n}^{* h}\right)+x_{s}^{h}\left(p_{s}^{h}, p_{s}^{* h}\right)\right]+g x_{s}^{h}\left(p_{s}^{h}, p_{s}^{* h}\right)+F \\
& C^{* h}=c^{*}\left[y_{n}^{h}\left(p_{n}^{h}, p_{n}^{* h}\right)+y_{s}^{h}\left(p_{s}^{h}, p_{s}^{* h}\right)\right]+g^{*} y_{n}^{h}\left(p_{n}^{h}, p_{n}^{* h}\right)+F^{*}
\end{aligned}
$$

Assumption 6: Each firm produces a similar quality product. But we introduce horizontal differentiation in order to avoid a Bertrand paradox. Demand functions are: $x_{i}^{h}=x_{i}^{h}\left(p_{i}^{h}, p_{i}^{* h}\right), y_{i}^{h}=$ $y_{i}^{h}\left(p_{i}^{h}, p_{i}^{* h}\right)$, for each market $i$ such as $i=n$, s. Domestic sales and exports decrease (increase) with

\footnotetext{
${ }^{12}$ To simplify profit expressions, we set: $x_{n}^{d}=x_{n}^{d}\left[p_{n}^{d}, p_{n}^{* d}, \theta(\phi)\right], x_{s}^{d}=x_{s}^{d}\left[p_{s}^{d}, p_{s}^{* d}, \theta(\phi)\right], c^{d}=c^{d}(\phi), y_{n}^{d}=$ $y_{n}^{d}\left[p_{n}^{d}, p_{n}^{* d}, \theta(\phi)\right], y_{s}^{d}=y_{s}^{d}\left[p_{s}^{d}, p_{s}^{* d}, \theta(\phi)\right]$.
} 
the domestic (foreign) firm's price: $\partial x_{i}^{h} / \partial p_{i}^{h}<0, \partial x_{i}^{h} / \partial p_{i}^{* h}>0, \partial y_{i}^{h} / \partial p_{i}^{h}>0, \partial y_{i}^{h} / \partial p_{i}^{* h}<0$. Own effects are stronger than crossed effects: $\left|\partial x_{i}^{h} / \partial p_{i}^{h}\right|>\partial x_{i}^{h} / \partial p_{i}^{* h}, \partial y_{i}^{h} / \partial p_{i}^{h}<\left|\partial y_{i}^{h} / \partial p_{i}^{* h}\right|$.

Profit expressions are the following:

$$
\begin{aligned}
& \Pi^{h}=p_{n}^{h} x_{n}^{h}+p_{s}^{h} x_{s}^{h}-c^{h}\left(x_{n}^{h}+x_{s}^{h}\right)-g x_{s}^{h}-F-v r \\
& \Pi^{* h}=p_{n}^{* h} y_{n}^{h}+p_{s}^{* h} y_{s}^{h}-c^{*}\left(y_{n}^{h}+y_{s}^{h}\right)-g^{*} y_{n}^{h}-F^{*}
\end{aligned}
$$

\subsection{Choice of R\&D Investment}

Let us call $E[$. $]$ the expectation operator with respect to the R\&D outcome. We denote by $\pi\left(\pi^{*}\right)$ the Northern (Southern) firm's profit, fixed and R\&D costs excluded: $\pi=\Pi+F+v r, \pi^{*}=\Pi^{*}+F^{*}$. We also use the superscripts $d$ and $h$ for the two cases.

Assumption 7: The Northern firm is encouraged to differentiate its product with respect to the product of its competitor. The Northern firm's profit increases with the degree of differentiation: $\mathrm{d} \pi^{d} / \mathrm{d} \phi>0$. The profit is stronger in case of a successful R\&D: $\pi^{d}>\pi^{h}$. The Northern firm would not be encouraged to invest in R\&D, otherwise. We also consider that the marginal profit is stronger when the R\&D is successful: $p_{i}^{d}-c^{d}>p_{i}^{h}-c^{h}, \forall i=\{n, s\}$.

The Northern firm's expected profit is:

$$
E[\Pi(r)]=\alpha(r) \hat{\pi}^{d}+[1-\alpha(r)] \hat{\pi}^{h}-F-v r
$$

The Northern firm selects the optimal R\&D investment level that maximizes such an expected profit. From the First Order Condition, we have:

$\alpha^{\prime}(r)=v /\left(\hat{\pi}^{d}-\hat{\pi}^{h}\right)$

A simple interpretation of the previous equation stems from rewriting the Northern firm's R\&D investment as a function of the difference in profit $\left(\hat{\pi}^{d}-\hat{\pi}^{h}\right)$ and of the R\&D unit cost $v: r=$ $\psi\left[v,\left(\hat{\pi}^{d}-\hat{\pi}^{h}\right)\right]$, with $\partial \psi / \partial\left(\hat{\pi}^{d}-\hat{\pi}^{h}\right)>0, \partial \psi / \partial v<0$. Therefore, we can study the impact of policy instruments on the R\&D investment by analyzing their impact on the difference in profit.

\section{Equilibrium with Linear Demand Functions}

Let us use now linear examples for demand functions and total cost functions for an easier demonstration. First consider the following function of consumers' taste for quality on each market:

$\theta(\phi)=\phi \eta$

The parameter $\eta$ denotes the sensitivity of the preference for quality with respect to the degree of differentiation, with $0<\eta \leq 1$. Demands now depend on $\phi \eta$. For each market $i$, we set the following demand functions:

$x_{i}=\left\{\begin{array}{c}x_{i}^{h}\left(p_{i}^{h}, p_{i}^{* h}\right)=a_{i}-b_{i} p_{i}^{h}+p_{i}^{* h}, \text { if } \phi=0 \\ x_{i}^{d}\left(p_{i}^{d}, p_{i}^{* d}, \phi \eta\right)=a_{i}(1+\phi \eta)-b_{i}(1-\phi \eta) p_{i}^{d}+(1+\phi \eta) p_{i}^{* d}, \text { otherwise. }\end{array}\right.$ 
$y_{i}=\left\{\begin{array}{c}y_{i}^{h}\left(p_{i}^{h}, p_{i}^{* h}\right)=a_{i}+p_{i}^{h}-b_{i} p_{i}^{* h}, \text { if } \phi=0 \\ y_{i}^{d}\left(p_{i}^{d}, p_{i}^{* d}, \phi \eta\right)=a_{\mathrm{i}}(1-\phi \eta)+(1-\phi \eta) p_{i}^{d}-b_{i}(1+\phi \eta) p_{i}^{* d}, \text { otherwise. }\end{array}\right.$

The parameter $a_{i}, \forall i=\{n, s\}$ denotes the fixed share of demand functions that does not depend on prices and quality. The parameter $b_{i}, \forall i=\{n, s\}$ denotes the horizontal differentiation between the two goods. We have: $b_{i}>1$. Under the unsuccessful case, each demand is more sensitive to the domestic firm's price compared to the foreign firm's price. Under the successful case, the following condition is necessary: $b_{i}>(1+\phi \eta) /(1-\phi \eta)$.

Note that in previous studies, authors first set a utility function to infer demand functions (Sutton, 1997; Symeonidis, 2003). Our methodology is reversed. We first set demand functions. The expression of consumer surplus is then given by integrating the demand functions. The consumer surplus increases with $\phi \eta$ (Mussa and Rosen, 1978).

Each firm selects the optimal levels of prices that maximize its profit. Under a successful R\&D, we have:

$$
\begin{aligned}
& \hat{p}_{n}^{d}=\frac{a_{n}\left(2 b_{n}+1\right)+2 b_{n}^{2} c^{d}(\phi)+b_{n}\left(c^{*}+g^{*}\right)+\phi \eta\left[a_{n}\left(2 b_{n}-1\right)-2 b_{n}^{2} c^{d}(\phi)+b_{n}\left(c^{*}+g^{*}\right)\right]}{\left(4 b_{n}^{2}-1\right)(1-\phi \eta)}, \\
& \hat{p}_{n}^{* d}=\frac{a_{n}\left(2 b_{n}+1\right)+b_{n} c^{d}(\phi)+2 b_{n}^{2}\left(c^{*}+g^{*}\right)-\phi \eta\left[a_{n}\left(2 b_{n}-1\right)+b_{n} c^{d}(\phi)-2 b_{n}^{2}\left(c^{*}+g^{*}\right)\right]}{\left(4 b_{n}^{2}-1\right)(1+\phi \eta)}, \\
& \hat{p}_{s}^{d}=\frac{a_{S}\left(2 b_{S}+1\right)+2 b_{s}^{2}\left[c^{d}(\phi)+g\right]+b_{s} c^{*}+\phi \eta\left[a_{s}\left(2 b_{s}-1\right)-2 b_{s}^{2}\left(c^{d}(\phi)+g\right)+b_{s} c^{*}\right]}{\left(4 b_{s}^{2}-1\right)(1-\phi \eta)}, \\
& \hat{p}_{s}^{* d}=\frac{a_{s}\left(2 b_{s}+1\right)+b_{S}\left[c^{d}(\phi)+g\right]+2 b_{s}^{2} c^{*}-\phi \eta\left[a_{s}\left(2 b_{s}-1\right)+b_{S}\left(c^{d}(\phi)+g\right)+2 b_{s}^{2} c^{*}\right]}{\left(4 b_{s}^{2}-1\right)(1+\phi \eta)}
\end{aligned}
$$

The Northern (Southern) firm's prices increase (decrease) with the degree of differentiation. When two goods are vertically differentiated, the higher quality good is more expensive. The difference in price between the two goods increases with the degree of differentiation.

The levels of domestic sales and exports for each firm are:

$$
\begin{aligned}
& \hat{x}_{n}^{d}=\frac{b_{n}\left\{a_{n}\left(2 b_{n}+1\right)-\left(2 b_{n}^{2}-1\right) c^{d}(\phi)+b_{n}\left(c^{*}+g^{*}\right)+\phi \eta\left[a_{n}\left(2 b_{n}-1\right)+\left(2 b_{n}^{2}-1\right) c^{d}(\phi)+b_{n}\left(c^{*}+g^{*}\right)\right]\right\}}{\left(4 b_{n}^{2}-1\right)}, \\
& \hat{y}_{n}^{d}=\frac{b_{n}\left\{a_{n}\left(2 b_{n}+1\right)+b_{n} c^{d}(\phi)-\left(2 b_{n}^{2}-1\right)\left(c^{*}+g^{*}\right)-\phi \eta\left[a_{n}\left(2 b_{n}-1\right)+b_{n} c^{d}(\phi)+\left(2 b_{n}^{2}-1\right)\left(c^{*}+g^{*}\right)\right]\right\}}{\left(4 b_{n}^{2}-1\right)}, \\
& \hat{x}_{s}^{d}=\frac{b_{s}\left\{a_{s}\left(2 b_{s}+1\right)-\left(2 b_{S}^{2}-1\right)\left[c^{d}(\phi)+g\right]+b_{S} c^{*}+\phi \eta\left[a_{s}\left(2 b_{s}-1\right)+\left(2 b_{s}^{2}-1\right)\left(c^{d}(\phi)+g\right)+b_{s} c^{*}\right]\right\}}{\left(4 b_{s}^{2}-1\right)}, \\
& \hat{y}_{S}^{d}=\frac{b_{S}\left\{a_{S}\left(2 b_{S}+1\right)+b_{S}\left[c^{d}(\phi)+g\right]-\left(2 b_{S}^{2}-1\right) c^{*}-\phi \eta\left[a_{S}\left(2 b_{S}-1\right)+b_{S}\left(c^{d}(\phi)+g\right)+\left(2 b_{S}^{2}-1\right) c^{*}\right]\right\}}{\left(4 b_{S}^{2}-1\right)}
\end{aligned}
$$

The Northern (Southern) firm's domestic sales and exports increase (decrease) with the degree of differentiation. The Northern firm's market share increases on both markets as compared to the situation without vertical differentiation.

Finally, consider that each firm's profit equals the sum of the profit earned on the domestic market and the profit earned on the foreign market: $\hat{\pi}^{d}=\hat{\pi}_{n}^{d}+\hat{\pi}_{s}^{d} ; \hat{\pi}^{* d}=\hat{\pi}_{n}^{* d}+\hat{\pi}_{s}^{* d}$. We have: 


$$
\begin{aligned}
& \hat{\pi}_{n}^{d}=\frac{b_{n}\left\{a_{n}\left(2 b_{n}+1\right)-\left(2 b_{n}^{2}-1\right) c^{d}(\phi)+b_{n}\left(c^{*}+g^{*}\right)+\phi \eta\left[a_{n}\left(2 b_{n}-1\right)+\left(2 b_{n}^{2}-1\right) c^{d}(\phi)+b_{n}\left(c^{*}+g^{*}\right)\right]\right\}^{2}}{\left(4 b_{n}^{2}-1\right)^{2}(1-\phi \eta)} \\
& \hat{\pi}_{S}^{d}=\frac{b_{S}\left\{a_{S}\left(2 b_{S}+1\right)-\left(2 b_{S}^{2}-1\right)\left[c^{d}(\phi)+g\right]+b_{S} c^{*}+\phi \eta\left[a_{S}\left(2 b_{S}-1\right)+\left(2 b_{S}^{2}-1\right)\left(c^{d}(\phi)+g\right)+b_{S} c^{*}\right]\right\}^{2}}{\left(4 b_{S}^{2}-1\right)^{2}(1-\phi \eta)} \\
& \hat{\pi}_{n}^{* d}=\frac{b_{n}\left\{a_{n}\left(2 b_{n}+1\right)+b_{n} c^{d}(\phi)-\left(2 b_{n}^{2}-1\right)\left(c^{*}+g^{*}\right)-\phi \eta\left[a_{n}\left(2 b_{n}-1\right)+b_{n} c^{d}(\phi)+\left(2 b_{n}^{2}-1\right)\left(c^{*}+g^{*}\right)\right]\right\}^{2}}{\left(4 b_{n}^{2}-1\right)^{2}(1+\phi \eta)} \\
& \hat{\pi}_{S}^{* d}=\frac{b_{S}\left\{a_{S}\left(2 b_{S}+1\right)+b_{S}\left[c^{d}(\phi)+g\right]-\left(2 b_{S}^{2}-1\right) c^{*}-\phi \eta\left[a_{S}\left(2 b_{S}-1\right)+b_{S}\left(c^{d}(\phi)+g\right)+\left(2 b_{S}^{2}-1\right) c^{*}\right]\right\}^{2}}{\left(4 b_{S}^{2}-1\right)^{2}(1+\phi \eta)}
\end{aligned}
$$

The Northern (Southern) firm's profit increases (decreases) with the degree of differentiation. Therefore, the difference in profit $\left(\hat{\pi}^{d}-\hat{\pi}^{h}\right)$ is positive.

Under an unsuccessful R\&D, we can find the equilibrium expressions of prices, outputs and profits by setting $\phi=0$ and $c^{d}(\phi)=c^{h}$.

Figure 1 illustrates a positive impact of the degree of differentiation on the difference in profit.

Figure 1 - Evolution of the difference in profit $\left(\widehat{\pi}^{d}-\widehat{\pi}^{h}\right)$ when $\phi$ varies

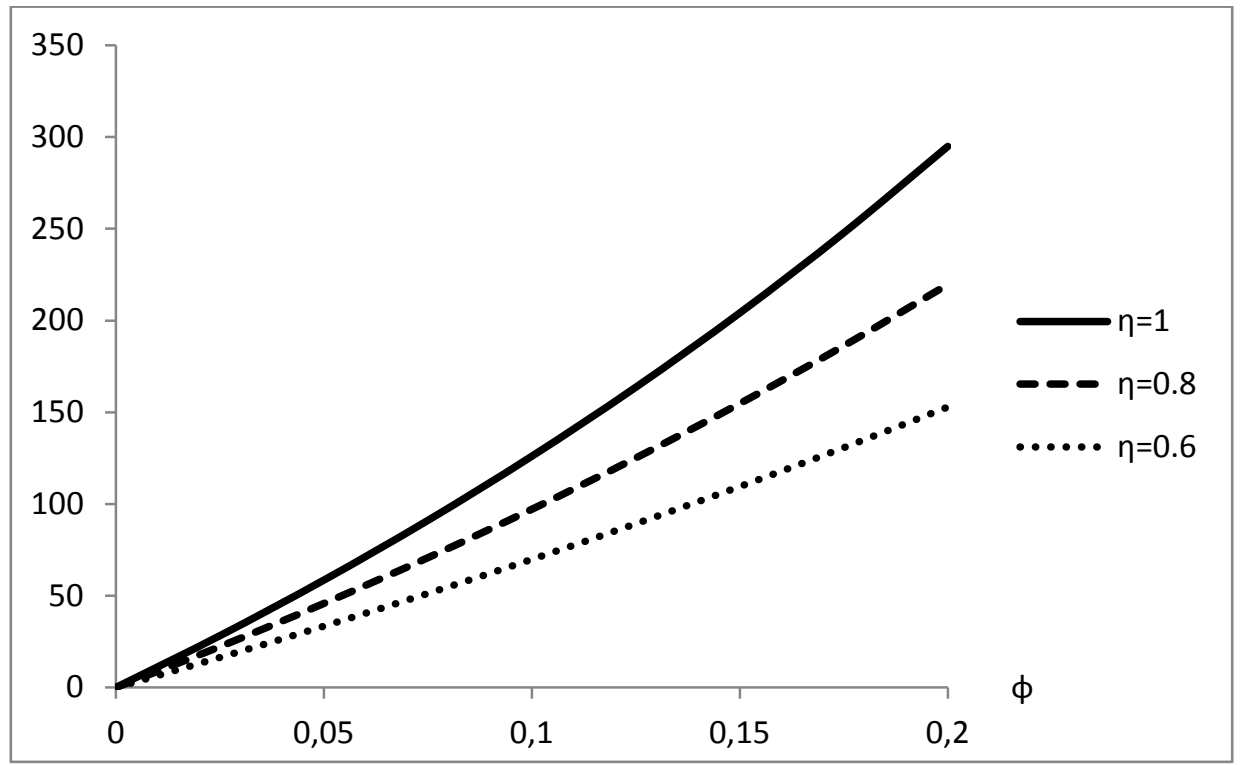

Source: authors.

Note: We set: $c^{d}(\phi)=c^{h}+\phi, a_{n}=40, a_{s}=30, b_{n}=b_{s}=2, c^{h}=6, c^{*}=3, g=g^{*}=1, F=$ $F^{*}=0$.

The Northern firm selects the optimal level of R\&D investment that maximizes its expected profit by taking into account the previous results. We know now the expressions of $\hat{\pi}^{d}$ and $\hat{\pi}^{h}$. We use the following function for the probability of R\&D success:

$\alpha(r)=r^{k}$, with $0<k<1$ 
Previously, we proved that the Northern firm is encouraged to invest in R\&D because the difference in profit increases with the degree of differentiation. Let us study now the impact on the Northern country's consumer surplus. As illustrated in Figure 2, the impact is negative for a low sensitivity $\eta$ of consumers' preference for quality improvement (for example if $\eta=0.2$ ). The lower $\eta$, the lower the consumers' preference for quality. Since vertical differentiation increases the Northern firm's price, the effect on the consumer surplus is then negative. The impact is positive, otherwise.

\section{Figure 2 - Evolution of the expected Northern consumer surplus when the R\&D investment varies}

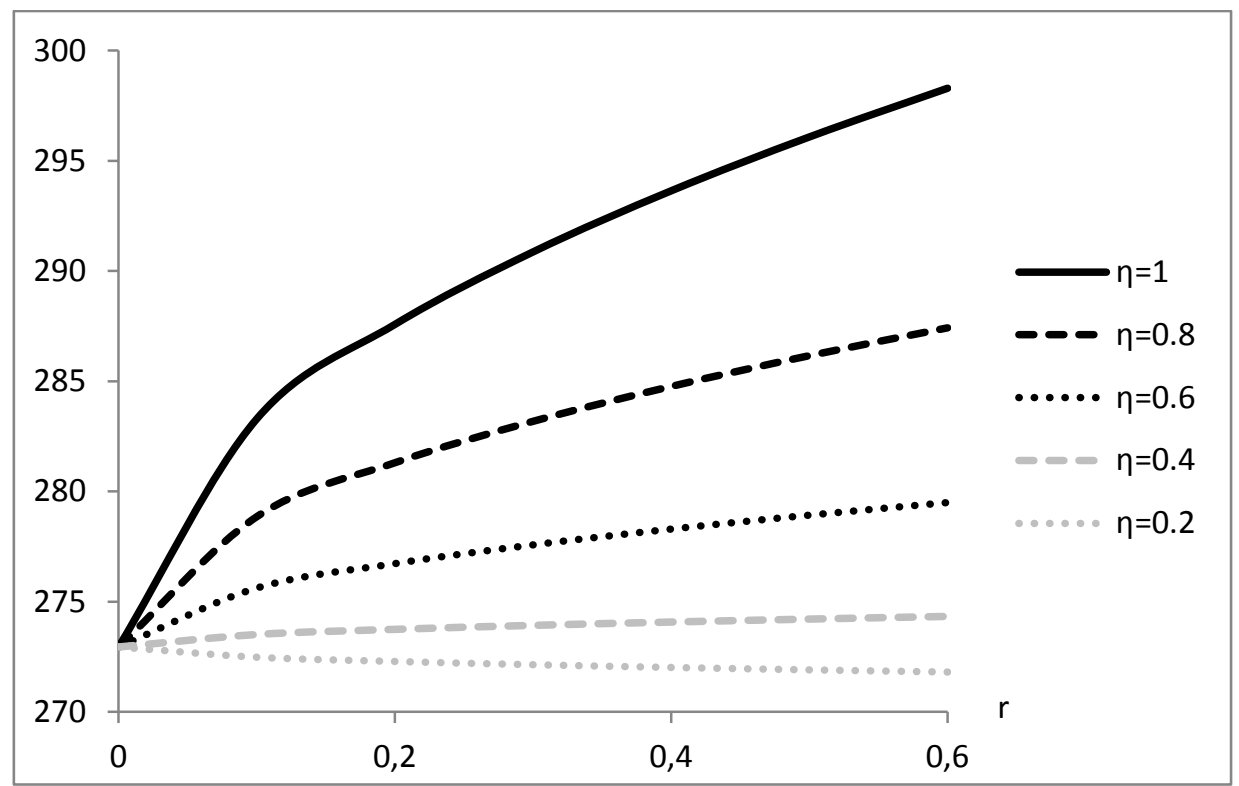

Source: authors.

Note: We set: $c^{d}(\phi)=c^{h}+\phi, a_{n}=40, a_{s}=30, b_{n}=b_{s}=2, c^{h}=6, c^{*}=3, g=g^{*}=1, \phi=$ $0.2, F=F^{*}=0$.

\section{Policy Instruments}

Let us study the impact of six policy instruments: an import tariff, a production subsidy, an R\&D subsidy, a quality standard, a minimum-price and an import quota. The Northern country's government may justify the implementation of these instruments by the increasing competition from an emerging country firm that benefits from a competitive advantage. Policy instruments aim to enhance the Northern firm's non-price competitiveness by increasing the probability of a successful R\&D outcome and to increase the Northern country's national welfare. The structure of the model is the following.

\section{Figure 3 - Structure of the model}




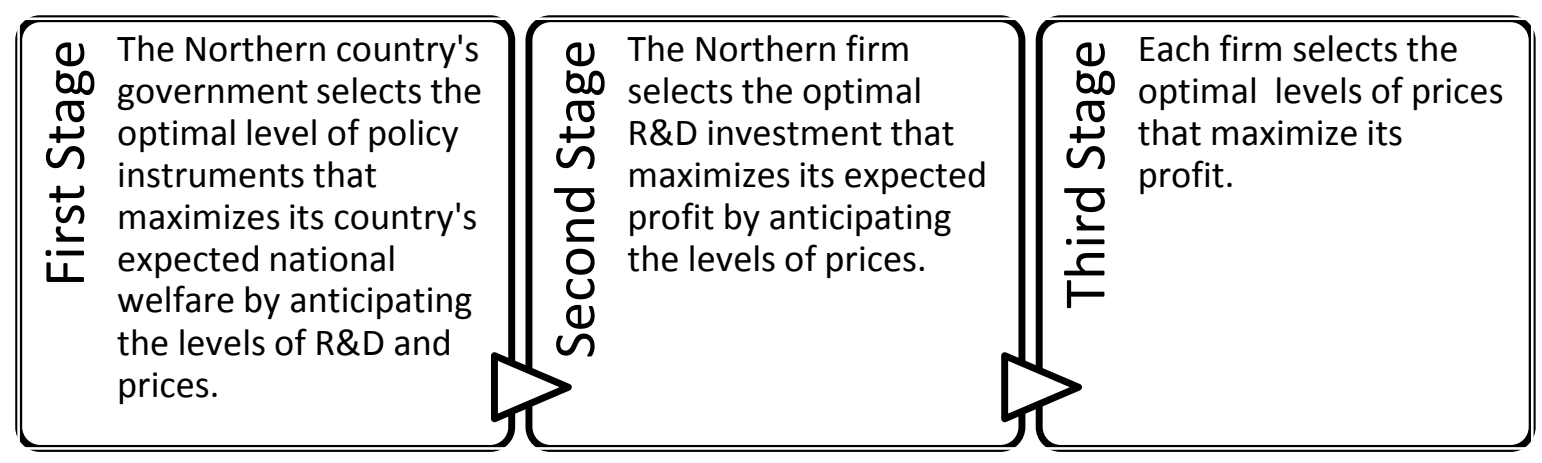

Source: authors.

The Northern country's government implements trade policy instruments that maximize the expected national welfare. The expression of the national welfare is:

$E(\mathrm{~W})=E(\Pi)+E(\mathrm{CS})+E(\mathrm{PR})$

The term W denotes the Northern country's national welfare; CS denotes the Northern country's consumer surplus; and PR denotes the governmental surplus i.e. public revenues. First, we look for the equilibrium levels of price. Then, we evaluate the impact of each policy instrument on the R\&D investment.

\subsection{An Import Tariff}

Consider that the Northern country's government implements an import tariff. We denote by $t$ the specific tariff on the Southern firm's exports. The Southern firm's profit expression changes as compared to free trade:

$\pi^{*}=\left\{\begin{array}{c}\pi^{* h}=p_{n}^{* h} y_{n}^{h}+p_{s}^{* h} y_{s}^{h}-c^{*}\left(y_{n}^{h}+y_{s}^{h}\right)-\left(t+g^{*}\right) y_{n}^{h}, \text { if } \phi=0 \\ \pi^{* d}=p_{n}^{* d} y_{n}^{d}+p_{s}^{* d} y_{s}^{d}-c^{*}\left(y_{n}^{d}+y_{s}^{d}\right)-\left(t+g^{*}\right) y_{n}^{d}, \text { otherwise }\end{array}\right.$

The tariff is a further marginal cost for the Southern firm, its economic impact is the same as that of an increase of $g^{*}$. As a result, the levels of price on the Northern market increase. The tariff also increases the Northern firm's domestic sales and profit, while it impacts negatively the Southern firm's exports and profit. ${ }^{13}$ Total sales on the Northern market decrease, therefore the implementation of an import tariff has a direct negative impact on the Northern country's consumer surplus. These results hold regardless of the outcome of the R\&D investment.

The Northern firm selects the optimal level of R\&D that maximizes its expected profit by taking into account the previous results.

Proposition 1: Under the specific functions, the Northern firm's R\&D investment increases with its domestic government's import tariff as compared to free trade.

Proof: Let us study the impact of the tariff on the difference in profit $\left[\hat{\pi}^{d}(\phi, \eta, t)-\hat{\pi}^{h}(t)\right]$. Note that the derivative of the difference is the difference of the derivatives:

\footnotetext{
${ }^{13}$ We note that there is no impact whatsoever on the Northern (Southern) firm's foreign (domestic) sales and prices. An increase (decrease) of the Northern (Southern) firm's profit is therefore due to an increase (decrease) of the profit earned on its domestic (foreign) market.
} 
$\frac{\mathrm{d}\left[\widehat{\pi}^{d}(\phi, \eta, t)-\widehat{\pi}^{h}(t)\right]}{\mathrm{d} t}=\frac{\mathrm{d} \hat{\pi}^{d}(\phi, \eta, t)}{\mathrm{d} t}-\frac{\mathrm{d} \widehat{\pi}^{h}(t)}{\mathrm{d} t}$

Furthermore, we already know that the Northern firm's profit increases with the tariff regardless of the R\&D outcome. We can study the impact of the degree of vertical differentiation on the positive impact of the tariff on the Northern firm's profit. Then, we have to study the sign of the second derivative $\mathrm{d}^{2} \hat{\pi}^{d}(\phi, \eta, t) /(\mathrm{d} t \mathrm{~d} \phi)$. In this case, we analyze the impact of an increase in $\phi$ from 0 to 1 on $\mathrm{d} \hat{\pi}^{d}(\phi, \eta, t) / \mathrm{d} t$. A positive result means that the positive impact of the tariff is higher when $\phi=1$ compared to the unsuccessful case when $\phi=0$.

To simplify the expressions, we set: $\hat{\pi}_{n}^{d}=\hat{\pi}_{n}^{d}(\phi, \eta, t)$. We have:

$\frac{\mathrm{d}^{2} \widehat{\pi}^{d}}{\mathrm{~d} t \mathrm{~d} \phi}=\frac{b_{n}^{3 / 2}\left(\widehat{\pi}^{d}\right)^{1 / 2}\left\{2 \eta+\left[\left(\mathrm{d} \hat{\pi}^{d} / \mathrm{d} \phi\right)\left(\widehat{\pi}^{d}\right)^{-1}+\eta(1-\phi \eta)^{-1}\right](1+\phi \eta)\right\}}{\left(4 b_{n}^{2}-1\right)(1-\phi \eta)^{1 / 2}}>0$

The previous expression is positive because, from Assumption 7, we have: $\mathrm{d} \hat{\pi}^{d} / \mathrm{d} \phi>0$. The other terms are positive. Therefore, the vertical differentiation increases the positive impact of the tariff on the Northern firm's profit. It can be deduced then, that the difference in profit increases with the tariff as compared to free trade. The Northern firm's R\&D expenditures also increase. The tariff leads to a gain for the Northern firm such as the latter is encouraged to invest more to benefit from a stronger gain. This can be explained by the intensity of competition from the Southern country. Since the tariff reduces imports from the low-cost country, the Northern firm is encouraged to increase its $R \& D$ investment in order to increase the probability of vertical differentiation and further reduce its competitor's exports. As a result, the cost of the tariff on the Southern firm's profit is greater in case of a successful R\&D, because the effect is all the more negative on its market share.

Nevertheless, we cannot demonstrate that these results hold under general forms for demand functions. The effect of the tariff on the difference in profit is always positive under any other linear form for demand functions. But under nonlinear forms, the results are unknown. ${ }^{14}$

The positive impact of the import tariff on the Northern firm's product R\&D investment relates to the positive impact on process R\&D investments illustrated in the economic literature (Krugman, 1984; Reitzes, 1991; Bouët, 2001). The tariff involves a profit-shifting from the South to the North. Such a profit-shifting is greater when the R\&D is successful. The Northern firm is therefore encouraged to innovate. Then, governments may improve their domestic non-price competitiveness by implementing trade policy instruments like tariffs.

\subsection{A Production Subsidy}

Consider now that the Northern country's government decides to subsidize the Northern firm's output (its domestic sales and exports). We denote by $s$ the specific production subsidy. The Northern firm's profit expressions change compared to free trade:

$\pi=\left\{\begin{array}{c}\pi^{h}=p_{n}^{h} x_{n}^{h}+p_{s}^{h} x_{s}^{h}-\left(c^{h}+s\right)\left(x_{n}^{h}+x_{s}^{h}\right)-g x_{s}^{h}, \text { if } \phi=0 \\ \pi^{d}=p_{n}^{d} x_{n}^{d}+p_{s}^{d} x_{s}^{d}-\left(c^{d}+s\right)\left(x_{n}^{d}+x_{s}^{d}\right)-g x_{s}^{d}, \text { otherwise. }\end{array}\right.$

\footnotetext{
${ }^{14}$ See Appendix A.
} 
In contrast to the specific tariff, the implementation of a production subsidy has repercussions on both the Northern and Southern markets. Its economic impact is the same as that of a decrease of the marginal cost for the Northern firm. This results in a drop in prices on both markets. While, the impact of the subsidy on the Northern firm's output and profit is positive, its Southern competitor's levels of domestic sales, exports and profit decrease. Nevertheless, the overall sales on the Northern and Southern markets both increase. There is a direct positive impact on the Northern country's consumer surplus.

Proposition 2: The Northern firm's R\&D investment increases if the following condition were verified: $(1-\phi \eta)\left(\mathrm{d} \hat{\pi}_{i}^{d} / \mathrm{d} \phi\right)>\eta \hat{\pi}_{i}^{d}$. It decreases otherwise. Using numerical simulations, we only find cases in which the effect is positive.

Proof: Since the derivative of a sum is the sum of the derivatives, we have:

$\frac{\mathrm{d}^{2} \widehat{\pi}^{d}(\phi, \eta, s)}{\mathrm{d} s \mathrm{~d} \phi}=\frac{\mathrm{d}^{2} \widehat{\pi}_{n}^{d}(\phi, \eta, s)}{\mathrm{d} s \mathrm{~d} \phi}+\frac{\mathrm{d}^{2} \widehat{\pi}_{s}^{d}(\phi, \eta, s)}{\mathrm{d} s \mathrm{~d} \phi}$

We denote by $\pi_{i}, \forall i=\{n, s\}$ the Northern firm's profit share earned on the market $i$. Setting $\hat{\pi}_{i}^{d}=\hat{\pi}_{i}^{d}(\phi, \eta, s)$ to simplify expressions, we have:

$\frac{\mathrm{d}^{2} \widehat{\pi}_{i}^{d}}{\mathrm{~d} s \mathrm{~d} \phi}=\frac{b_{i}^{3 / 2}\left(2 b_{i}^{2}-1\right) \widehat{\pi}_{i}^{d^{1 / 2}}\left[(1-\phi \eta)\left(d \widehat{\pi}_{i}^{d} / d \phi\right) \widehat{\pi}_{i}^{d^{-1}}-\eta\right]}{\left(4 b_{i}^{2}-1\right)(1-\phi \eta)^{1 / 2}}, \forall i=\{n, s\}$

The sign of the term in brackets is undetermined. Therefore, the impact of the subsidy on the difference in profit is uncertain. The expression above would be positive if the following condition were verified: $(1-\phi \eta)\left(\mathrm{d} \hat{\pi}_{i}^{d} / \mathrm{d} \phi\right)>\eta \hat{\pi}_{i}^{d}$. We offer the following economic explanation to this inconclusive mathematical result. Following the implementation of the production subsidy by the Northern country's government, both markets experience a fall in prices. The magnitude of the effect is however, greater for the Northern firm. As a result, its domestic sales and exports increase. The increase is even bigger when compared for example, to the case of a tariff implementation. As stated previously, the main feature of vertical differentiation is the change in demand functions. In case of a production subsidy, the increase of demand for the Northern firm's good is such as the Northern firm may be less encouraged to increase its R\&D investment. Nevertheless, taking numerical values for parameters, we always find a positive impact of the production subsidy on the difference in profit. The Northern firm is generally encouraged to increase its R\&D investment because the revenues of the subsidy increase with the level of output. Such a level increases with vertical differentiation. The effect of the production subsidy on the R\&D investment is positive in this case, because the output effect is stronger than the price effect.

\subsection{An R\&D Subsidy}

Consider now the case in which the Northern country's government subsidizes its domestic firm's $R \& D$ investment instead of its production. We denote by $\sigma$ such a specific subsidy that reduces the total cost of R\&D. The Northern firm's expected profit changes compared to free trade:

$E[\Pi(r, \sigma)]=\alpha(r) \hat{\pi}^{d}+[1-\alpha(r)] \hat{\pi}^{h}-(v-\sigma) r$

The optimal R\&D investment is now: 
$r(\sigma)=\left[\frac{k\left(\widehat{\pi}^{d}-\widehat{\pi}^{h}\right)}{v-\sigma}\right]^{\frac{1}{1-k}}$

The R\&D subsidy does not directly influence prices and outputs. But there is an indirect impact by influencing the Northern firm's R\&D expenditures and the probability of R\&D success.

Proposition 3: The Northern firm's R\&D investment increases with its government's R\&D subsidy as compared to the initial situation without subsidy.

Proof: The subsidy $\sigma$ reduces the denominator of $r(\sigma)$. Then, the R\&D investment increases with the R\&D subsidy: $\mathrm{d} r(\sigma) / \mathrm{d} \sigma>0$. The Northern firm is encouraged to increase its R\&D investment because the total cost of R\&D is lower.

\subsection{A Quality Standard}

The Northern country's government can decide to implement a quality standard on the domestic market regardless of the outcome of the R\&D. In this case, the introduction of a quality standard gives the Northern firm a monopoly power on the Northern market if the R\&D is successful, since its competitor produces a lower quality good and does not meet the standard. Then, the demand for the Northern firm's product no longer depends on the Southern firm's price. But if the R\&D is unsuccessful, there is no market in the Northern country.

We use the superscripts $h s$ and $d s$ for variables with the quality standard. Under the successful case, we set $y_{n}^{d s}=0$ in order to express $p_{n}^{* d}$ as a function of $p_{n}^{d}$. We deduce the following demand function for the Northern firm's product sold on its domestic market:

$x_{n}^{d s}\left(p_{n}^{d s}, \phi \eta\right)=\left\{a_{n}\left[b_{n}(1+\phi \eta)+1-\phi \eta\right]-\left(b_{n}^{2}-1\right)(1-\phi \eta) p_{n}^{d s}\right\} / b$

Prices and demand functions on the Southern market are unchanged. For example, $x_{s}^{d}$ still denotes the Northern firm's exports. The profit expressions are:

$\pi=\left\{\begin{array}{c}\pi^{h s}=p_{s}^{h} x_{s}^{h}-\left(c^{h}+g\right) x_{s}^{h}, \text { if } \phi=0 \\ \pi^{d s}=p_{n}^{d s} x_{n}^{d s}+p_{s}^{d} x_{s}^{d}-c^{d}\left(x_{n}^{d s}+x_{s}^{d}\right)-g x_{s}^{d}, \text { otherwise. }\end{array}\right.$

$\pi^{*}=\left\{\begin{array}{c}\pi^{* d h}=p_{s}^{* h} y_{s}^{h}-c^{*} y_{s}^{h}, \text { if } \phi=0 \\ \pi^{* d s}=p_{s}^{* d} y_{s}^{d}-c^{*} y_{s}^{d}, \text { otherwise }\end{array}\right.$

With a successful R\&D, the Northern firm's equilibrium price of domestic sales is:

$\hat{p}_{n}^{d s}(\phi, \eta)=\frac{a_{n}\left(b_{n}+1\right)+\left(b_{n}^{2}-1\right) c^{d}(\phi)+\phi \eta\left[a_{n}\left(b_{n}-1\right)-\left(b_{n}^{2}-1\right) c^{d}(\phi)\right]}{2\left(b_{n}^{2}-1\right)(1-\phi \eta)}$

Since there is no longer competition from the Southern firm, the Northern firm's price on its domestic market increases as compared to free trade in case of a successful R\&D investment. The monopoly situation relates to a case in which the Southern firm sets a level of price of exports approaching infinity. According to the reaction functions under the initial case without quality standard, the Northern firm's domestic price increases with the Southern firm's foreign price: $\mathrm{d} p_{n}^{d} / \mathrm{d} p_{n}^{* d}=$ $(1+\phi \eta) /\left[2 b_{n}(1-\phi \eta)\right]>0$. This result entails that the Northern firm's domestic price is higher as compared to the initial case. 
The Northern firm's domestic sales are:

$\hat{x}_{n}^{d s}(\phi, \eta)=\frac{a_{n}\left(b_{n}+1\right)-\left(b_{n}^{2}-1\right) c^{d}(\phi)+\phi \eta\left[a_{n}\left(b_{n}-1\right)+\left(b_{n}^{2}-1\right) c^{d}(\phi)\right]}{2 b_{n}}$

The Northern firm's domestic sales also increase when a quality standard is implemented. By the same reasoning as above we have: $\mathrm{d} x_{n}^{d} / \mathrm{d} p_{n}^{* d}=\left(\partial x_{n}^{d} / \partial p_{n}^{d}\right)\left(\mathrm{d} p_{n}^{d} / \mathrm{d} p_{n}^{* d}\right)+\partial x_{n}^{d} / \partial p_{n}^{* d}=$ $(1+\phi \eta) / 2>0$. However, total sales on the Northern market decrease because the Southern firm leaves the market and the domestic price increases.

Finally, the Northern firm's profit earned on its domestic market equals:

$\hat{\pi}_{n}^{d s}(\phi, \eta)=\frac{a_{n}\left(b_{n}+1\right)-\left(b_{n}^{2}-1\right) c^{d}(\phi)+\phi \eta\left[a\left(b_{n}-1\right)+\left(b_{n}^{2}-1\right) c^{d}(\phi)\right]}{4 b_{n}\left(b_{n}^{2}-1\right)(1-\phi \eta)}$

Given the monopoly situation, the Northern firm's optimal level of profit is greater as compared to free trade, since the maximization process does not involve taking into account any constraints regarding its rival firm. Moreover, the Northern firm sets a higher price and its marginal profit increases. Its level of output is also stronger.

We now look for the impact of the quality standard on the Northern firm's R\&D investment. The equilibrium level of $R \& D$ is given by:

$r=\left[\frac{k\left(\widehat{\pi}^{d s}-\widehat{\pi}^{h s}\right)}{v}\right]^{\frac{1}{1-k}}$

Proposition 4: The Northern firm's R\&D investment increases with the implementation of the quality standard.

Proof: The quality standard only increases the Northern firm's profit if the R\&D is successful. With an unsuccessful R\&D, such a profit decreases because there is no market in the North while the profit earned in the South is the same as compared to the initial case. Then, the difference in profit increases as compared to the initial case: $\left(\hat{\pi}^{d s}-\hat{\pi}^{h s}\right)>\left(\hat{\pi}^{d}-\hat{\pi}^{h}\right)$. The Northern firm increases its $R \& D$ investment in order to increase the probability of R\&D success, and then, to benefit from the monopoly in the North with the quality standard.

\subsection{A Minimum-Price}

The quality standard is a prohibitive quota in case of a successful R\&D. The Northern country's government can also implement price restrictions. Consider a minimum-price such as the Southern firm cannot sell its product on the Northern market with a lower price. We denote by $p_{\min }$ the minimum-price for the Southern firm. The Southern firm's profit expression is now:

$\pi^{*}=\left\{\begin{array}{c}\pi^{* h}=p_{\min } y_{n}^{h}+p_{s}^{* h} y_{s}^{h}-c^{*}\left(y_{n}^{h}+y_{s}^{h}\right)-g^{*} y_{n}^{h}, \text { if } \phi=0 \\ \pi^{* d}=p_{\min } y_{n}^{d}+p_{s}^{* d} y_{s}^{d}-c^{*}\left(y_{n}^{d}+y_{s}^{d}\right)-g^{*} y_{n}^{d}, \text { otherwise. }\end{array}\right.$

The Northern country's government can select two levels of minimum-price:

A relatively binding minimum-price such as: $p_{n}^{* d}<p_{\min } \leq p_{n}^{* h}$. The minimum-price has only an economic impact if the R\&D is successful. The effect is null when the R\&D is unsuccessful. 
A very binding minimum-price such as: $p_{\min }>p_{n}^{* h}$. The minimum-price has an impact regardless of the R\&D outcome.

Note that there is a third case in which the minimum-price is not binding: $p_{\min } \leq p_{n}^{* d}$. We do not study this case because the effect of the minimum-price would be null. Only the Northern firm selects the optimal level of price that maximizes its profit. Under a successful R\&D, we have:

$\hat{p}_{n}\left(\phi, \eta, p_{\min }\right)=\frac{a_{n}+b_{n} c^{d}(\phi)+p_{\min }+\phi \eta\left[a_{n}-b_{n} c^{d}(\phi)+p_{\min }\right]}{2 b_{n}(1-\phi \eta)}$

The Northern firm's domestic sales and Southern firm's exports are respectively:

$$
\begin{aligned}
& \hat{x}_{n}\left(\phi, \eta, p_{\min }\right)=\frac{a_{n}-b_{n} c^{d}(\phi)+p_{\min }+\phi \eta\left[a_{n}+b_{n} c^{d}(\phi)+p_{\min }\right]}{2} \\
& \hat{y}_{n}\left(\phi, \eta, p_{\min }\right)=\frac{a_{n}\left(2 b_{n}+1\right)+b_{n} c^{d}(\phi)-p_{\min }\left(2 b_{n}^{2}-1\right)-\phi \eta\left[a_{n}\left(2 b_{n}-1\right)+b_{n} c^{d}(\phi)+p_{\min }\left(2 b_{n}^{2}-1\right)\right]}{2 b_{n}}
\end{aligned}
$$

The Northern firm's domestic price increases as compared to free trade because prices are strategic complements under Bertrand competition. Meanwhile, the Southern firm's export sales decrease with the minimum-price because its price of exports is higher as compared to free trade. Conversely, the effect on the Northern firm's output is positive even if its price increases. The minimum-price increases the Northern firm's market share.

The equilibrium profit shares earned on the Northern market are:

$$
\begin{aligned}
& \hat{\pi}_{n}^{d}\left(\phi, \eta, p_{\min }\right)=\frac{\left\{a_{n}-b_{n} c^{d}(\phi)+p_{\min }+\phi \eta\left[a_{n}+b_{n} c^{d}(\phi)+p_{\min }\right]\right\}^{2}}{4 b_{n}(1-\phi \eta)} \\
& \hat{\pi}_{n}^{* d}\left(\phi, \eta, p_{\min }\right)=\frac{\left\{a_{n}\left(2 b_{n}+1\right)+b_{n} c^{d}(\phi)-p_{\min }\left(2 b_{n}^{2}-1\right)-\phi \eta\left[a_{n}\left(2 b_{n}-1\right)+b_{n} c^{d}(\phi)+p_{\min }\left(2 b_{n}^{2}-1\right)\right]\right\}\left(p_{\min }-c^{*}\right)}{2 b_{n}}
\end{aligned}
$$

The Northern firm's profit increases with the minimum-price. The impact is also positive in case of an unsuccessful R\&D. However, the instrument reduces the Southern firm's profit earned on the Northern market, because the Southern firm cannot maximize its profit anymore.

Proposition 5: The Northern firm's R\&D investment increases with both a relatively and a very binding minimum-price.

Proof: We consider two cases:

First let us study the impact of the relatively binding minimum-price. In case of an unsuccessful R\&D investment, the Northern firm's profit is the same as under free trade. This profit increases as compared to free trade with a successful R\&D. Then, the difference in profit increases with the relatively binding minimum-price.

Now let us study the impact of the very binding minimum-price. The Northern firm's profit increases as compared to free trade regardless of the R\&D outcome. Since a relatively binding minimum-price increases the difference in profit, we can derivate the Northern firm's profit with respect to the minimum-price and to the degree of differentiation. Setting $\hat{\pi}_{n}^{d}=\hat{\pi}_{n}^{d}\left(\phi, \eta, p_{\min }\right)$ to simplify expressions, we have: 
$\frac{\mathrm{d}^{2} \widehat{\pi}_{n}^{d}}{\mathrm{~d} p_{\min } \mathrm{d} \phi}=\frac{\widehat{\pi}_{n}^{d^{1 / 2}}\left\{2 \eta+(1+\phi \eta)\left(\mathrm{d} \widehat{\pi}_{n}^{d} / \mathrm{d} \phi\right) \widehat{\pi}_{n}^{d^{-1}}+\eta(1+\phi \eta)(1-\phi \eta)^{-1}\right\}}{\left[4 b_{n}(1-\phi \eta)\right]^{1 / 2}}>0$

The positive impact of $p_{\min }$ on $\hat{\pi}_{n}^{d}$ increases with $\phi$. Then, the difference in profit also increases with the very binding minimum-price.

Therefore, the Northern firm's R\&D investment increases with the minimum-price as compared to free trade. The impact is positive with both the relatively and very binding minimum-price.

\subsection{An Import Quota}

Let us study the impact of an import quota implemented by the Northern government. We have analyzed the impact of a quality standard i.e. a prohibitive quota. But governments can also implement traditional quotas. Consider a binding quota denoted by $q$ that corresponds to the maximum level of exports for the Southern firm. Studying the impact of a quota under Bertrand competition is complex owing to demand functions that depend on each level of price. Under free trade, when the R\&D is successful, we can express the Southern firm's price of exports as a function of the Northern firm's price of domestic sales and of the Southern firm's exports: $p_{n}^{* d}=\left[\left(a_{n}+p_{n}^{d}\right)(1-\phi \eta)-y_{n}^{d}\right] /\left[b_{n}(1+\phi \eta)\right]$. Then, with a binding quota, we have:

$p_{n}^{* d}\left(p_{n}^{d}, \phi \eta, q\right)=\left[\left(a_{n}+p_{n}^{*}\right)(1-\phi \eta)-q\right] /\left[b_{n}(1+\phi \eta)\right]$

Such an expression is the Southern firm's best-response to the Northern firm's price of domestic sales (Krishna, 1989). It also depends on the level of the quota, since the quota is binding. Then, the Southern firm no longer maximizes its profit with respect to its price of exports. It only reacts to the levels of $p_{n}^{d}$ and $q$.

Integrating the expression of $p_{n}^{* d}$ in $x_{n}^{d}$, we have:

$x_{n}^{d}\left(p_{n}^{d}, \phi \eta, q\right)=\left\{a_{n}\left[b_{n}(1+\phi \eta)+1-\phi \eta\right]-(1-\phi \eta)\left(b_{n}^{2}-1\right) p_{n}^{d}-q\right\} / b_{n}$

The demand for the Northern firm's good on the Northern market no longer depends on the level of the Southern firm's price of exports because such a price is a response to the Northern firm's price of domestic sales and to the level of the quota.

The Northern firm's profit expression is the same as in Equation (1) but $x_{n}^{d}$ now depends on the level of the quota $q$. The Southern firm's profit expression is now:

$\pi^{*}=\left\{\begin{array}{c}\pi^{* h}=q p_{n}^{* h}+p_{s}^{* h} y_{s}^{h}-c^{*}\left(q+y_{s}^{h}\right)-g^{*} q, \text { if } \phi=0 \\ \pi^{* d}=q p_{n}^{d}+p_{s}^{* d} y_{s}^{d}-c^{*}\left(q+y_{s}^{d}\right)-g^{*} q, \text { otherwise. }\end{array}\right.$

The quota does not influence the outcome on the Southern market. On the Northern market, the Northern firm selects the optimal price of domestic sales:

$\hat{p}_{n}^{d}(\phi, \eta, q)=\frac{a_{n}\left(b_{n}+1\right)+c^{d}(\phi)\left(b_{n}^{2}-1\right)-q+\phi \eta\left[a_{n}\left(b_{n}-1\right)-c^{d}(\phi)\left(b_{n}^{2}-1\right)\right]}{2\left(b_{n}^{2}-1\right)(1-\phi \eta)}$

The Northern firm's price of domestic sales increases with a binding quota as compared to free trade owing to the drop in the competition from the Southern country. 
The Southern firm's best-response is:

$\hat{p}_{n}^{* d}(\phi, \eta, q)=\frac{a_{n}\left(2 b_{n}^{2}+b_{n}-1\right)-q\left(2 b_{n}^{2}-1\right)-\phi \eta\left[a_{n}\left(2 b_{n}^{2}-b_{n}-1\right)+c^{d}(\phi)\left(b_{n}^{2}-1\right)\right]}{2 b_{n}\left(b_{n}^{2}-1\right)(1+\phi \eta)}$

The Southern firm's price of exports also increases with a binding quota as compared to free trade.

The Northern firm's domestic sales equal:

$\hat{x}_{n}^{d}(\phi, \eta, q)=\frac{a_{n}\left(b_{n}+1\right)-c^{d}(\phi)\left(b_{n}^{2}-1\right)-q+\phi \eta\left[a_{n}\left(b_{n}-1\right)+c^{d}(\phi)\left(b_{n}^{2}-1\right)\right]}{2 b_{n}}$

The Northern firm's domestic sales increase with a binding quota as compared to free trade.

Finally, the equilibrium profits on the Northern market are:

$\hat{\pi}_{n}^{d}(\phi, \eta, q)=\frac{\left\{a_{n}\left(b_{n}+1\right)-c^{d}(\phi)\left(b_{n}^{2}-1\right)-q+\phi \eta\left[a_{n}\left(b_{n}-1\right)+c^{d}(\phi)\left(b_{n}^{2}-1\right)\right]\right\}^{2}}{4 b_{n}\left(b_{n}^{2}-1\right)(1-\phi \eta)}$

$\hat{\pi}_{n}^{* d}(\phi, \eta, q)=$

$\frac{q\left\{a_{n}\left(2 b_{n}^{2}+b_{n}-1\right)-2 b_{n}\left(b_{n}^{2}-1\right)\left(c^{*}+g^{*}\right)-q\left(2 b_{n}^{2}-1\right)-\phi \eta\left[a_{n}\left(2 b_{n}^{2}-b_{n}-1\right)+c^{d}(\phi)\left(b_{n}^{2}-1\right)+2 b_{n}\left(b_{n}^{2}-1\right)\left(c^{*}+g^{*}\right)\right]\right\}}{2 b_{n}\left(b_{n}^{2}-1\right)(1+\phi \eta)}$

The Northern firm's profit increases with a binding quota as compared to free trade. The Southern firm's profit decreases because it no longer sets the optimal level of price that maximizes its profit. It only sets the best response to $q$ and $p_{n}^{d}$.

We consider two cases: a relatively binding quota and a very binding quota.

First case: $\hat{y}_{n}^{d}(\phi, \eta) \leq q<\hat{y}_{n}^{h}$. The quota is relatively binding because it only reduces the Southern firm's exports when the R\&D is unsuccessful. The Northern firm's profit only increases as compared to free trade under this case: $\hat{\pi}_{n}^{h}(q)>\hat{\pi}_{n}^{h}, \hat{\pi}_{n}^{d}(q)=\hat{\pi}_{n}^{d}$.

Second case: $q<\hat{y}_{n}^{d}(\phi, \eta)$. The quota is very binding because it reduces the Southern firm's exports under both cases. Then, the Northern firm's profit increases as compared to free trade regardless of the R\&D outcome: $\hat{\pi}_{n}^{h}(q)>\hat{\pi}_{n}^{h}, \hat{\pi}_{n}^{d}(q)>\hat{\pi}_{n}^{d}$.

Proposition 6: The Northern firm's R\&D investment decreases with a relatively binding quota and either increases or decreases with a very binding quota as compared to free trade. There is a non-null value of quota $\bar{q}$ such as the R\&D investment equals the free trade level. Then, the Northern firm's R\&D investment decreases as compared to free trade when $q \in\left(\bar{q}, \hat{y}_{n}^{d}\right)$, levels off when $q=\bar{q}$, and increases when $q \in[0, \bar{q})$.

Proof: Let us consider the two cases:

With a relatively binding quota, the quota is only binding when the R\&D is unsuccessful. The Northern firm's profit only increases under this case. Then, the difference in profit decreases as compared to free trade: $\hat{\pi}_{n}^{d}(\phi, \eta, q)-\hat{\pi}_{n}^{h}(q)<\hat{\pi}_{n}^{d}(\phi, \eta)-\hat{\pi}_{n}^{h}$.

With a very binding quota, the quota is binding under both cases. The Northern firm's profit increases regardless of the R\&D outcome. We have: 
$\frac{\mathrm{d} \widehat{\pi}_{n}^{d}(\phi, \eta, q)}{\mathrm{d} q}=-\frac{2 \hat{x}_{n}^{d}(\phi, \eta, q)}{2\left(b_{n}^{2}-1\right)(1-\phi \eta)}<0$

The positive effect of a drop in $q$ on $\pi$ equals $2 \hat{x}_{n}^{d}(\phi, \eta, q) /\left[2\left(b_{n}^{2}-1\right)(1-\phi \eta)\right]$. Such an expression increases with $\phi$ because $\mathrm{d} \hat{x}_{n}^{d}(\phi, \eta, q) / \mathrm{d} \phi>0$. The positive effect of the quota on the Northern firm's profit is greater when the R\&D is successful. Then, the difference in profit increases when the level of the quota decreases. But, since a relatively binding quota reduces the R\&D, such a result is not sufficient to prove that the difference in profit always increases as compared to free trade. We denote by $\bar{q}$ the quota such as the difference in profit equals the free trade level. The difference in profit decreases with a very binding quota $q$ such as $q \in\left(\bar{q}, \hat{y}_{n}^{d}\right)$ if $0<\bar{q}<\hat{y}_{n}^{d}$. The difference in profit always decreases with a very binding quota if $\bar{q}=0$. It always increases, otherwise.

Then, the Northern firm's R\&D investment decreases with a relatively binding quota, and either increases or decreases with a very binding quota. Let us use a numerical example. Figure 4 illustrates the evolution of the Northern firm's R\&D investment when the level of the quota varies. The grey line illustrates the free trade level. Here, we find $\bar{q} \approx 12.1738$, with $0<\bar{q}<\hat{y}_{n}^{d}$. Then, under such a numerical example, the R\&D investment decreases with a very binding quota as compared to free trade if $q \in\left(\bar{q}, \hat{y}_{n}^{d}\right)$. It levels off if $q=\bar{q}$. It increases if $q \in[0, \bar{q})$.

\section{Figure 4 - Evolution of the Northern firm's R\&D Investment When $q$ Varies}

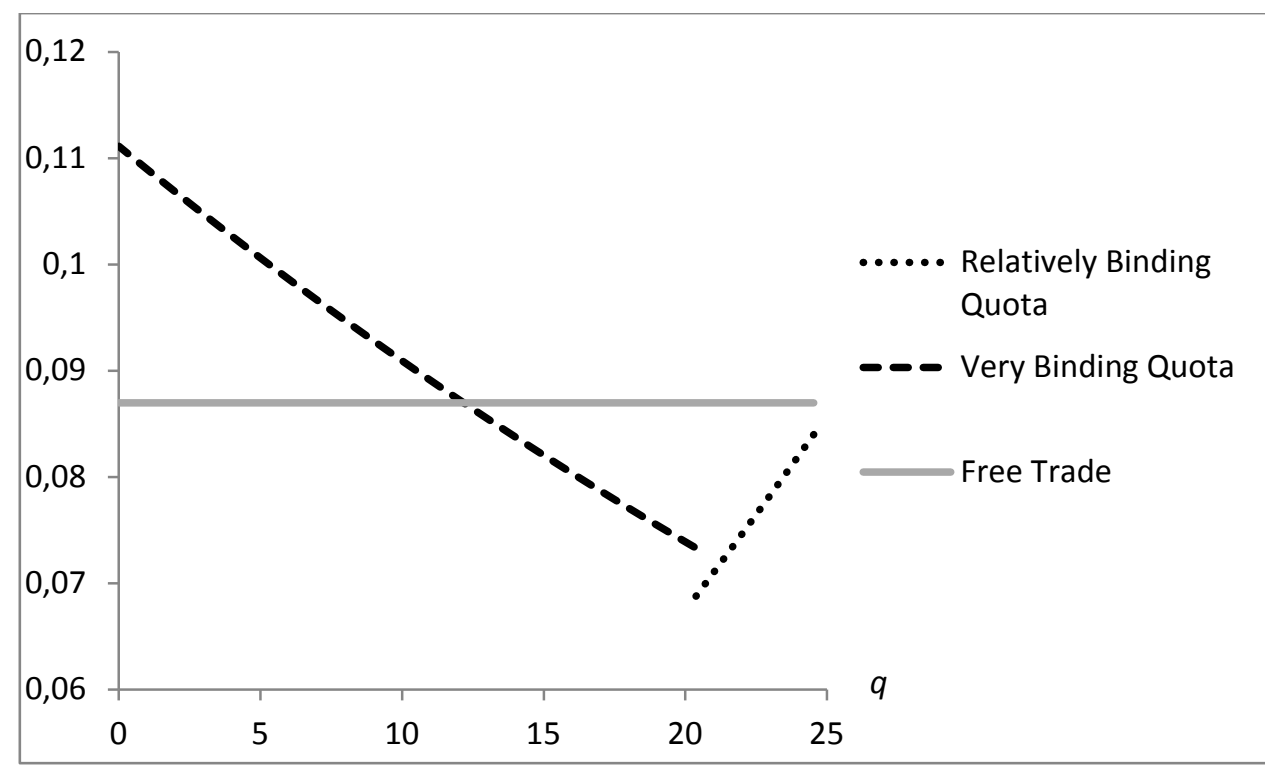

Source: authors.

Note: $\quad c^{d}(\phi)=c^{h}+\phi, \alpha(r)=r^{k}, a_{n}=40, a_{s}=30, b_{n}=b_{s}=2, c^{h}=6, c^{*}=3, g=g^{*}=1, \phi=$ $0.2, \eta=1, v=500, k=0.5, F=F^{*}=0$.

This is the first paper that studies the impact of import quotas on product R\&D investments. As with the tariff, the negative impact of the relatively binding import quota relates to the negative impact on process R\&D mentioned in the theoretical economic literature (Reitzes, 1991; Bouët, 2001). For example, Bouët (2001) designs a North-South theoretical framework and finds a negative impact of a voluntary export restraint implemented by the Southern country on the Northern firm's R\&D investment. He also finds a positive impact of an import tariff implemented by the Northern government. The economic literature explains the difference between these instruments by 
mentioning that a quota changes the strategic relationship between firms while a tariff does not (Bhagwati, 1968; Krishna, 1989). With the quota, the Northern firm benefits from an advantage in terms of information. Since the quota is binding, the Northern firm already knows the level of its competitor's exports before selecting its domestic sales. The Southern firm no longer sets the optimal level of exports. On the Northern market, the Northern firm selects the optimal level of domestic sales without considering the Southern firm's first order condition.

\section{Welfare Analysis}

We have examined the impact of six policy instruments on the Northern firm's R\&D investment. Let us study the economic impact of each instrument by analyzing their impact on expected profits, consumer surplus and public revenues.

\subsection{General Framework under Free Trade}

Each expected variable depends on the equilibrium expression of the R\&D investment $\hat{r}$.

Expected profits are:

$E[\widehat{\Pi}(\hat{r})]=\alpha(\hat{r}) \hat{\pi}^{d}+[1-\alpha(\hat{r})] \hat{\pi}^{h}-v r, E\left[\widehat{\Pi}^{*}(\hat{r})\right]=\alpha(\hat{r}) \hat{\pi}^{* d}+[1-\alpha(\hat{r})] \hat{\pi}^{* h}$

Let us study each country's expected consumer surplus. We need to express the domestic (foreign) price as a function of the domestic (foreign) sales by turning the domestic (foreign) demand function and considering the foreign (domestic) price as a parameter. We have:

$$
\begin{aligned}
& E[\widehat{\mathrm{CS}}(\hat{r})]=\alpha(\hat{r})\left[\int_{0}^{\hat{x}_{n}^{d}} p_{n}^{d}\left(x_{n}^{d}\right) \mathrm{d} x_{n}^{d}-p_{n}^{d}\left(\hat{x}_{n}^{d}\right) \hat{x}_{n}^{d}+\int_{0}^{\hat{y}_{n}^{d}} p_{n}^{* d}\left(y_{n}^{d}\right) \mathrm{d} y_{n}^{d}-p_{n}^{* d}\left(\hat{y}_{n}^{d}\right) \hat{y}_{n}^{d}\right]+[1- \\
& \alpha(\hat{r})]\left[\int_{0}^{\hat{x}_{n}^{h}} p_{n}^{h}\left(x_{n}^{h}\right) \mathrm{d} x_{n}^{h}-p_{n}^{h}\left(\hat{x}_{n}^{h}\right) \hat{x}_{n}^{h}+\int_{0}^{\hat{y}_{n}^{h}} p_{n}^{* h}\left(y_{n}^{h}\right) \mathrm{d} y_{n}^{h}-p_{n}^{* h}\left(\hat{y}_{n}^{h}\right) \hat{y}_{n}^{h}\right] \\
& E\left[\widehat{\mathrm{CS}}^{*}(\hat{r})\right]=\alpha(\hat{r})\left[\int_{0}^{d} p_{s}^{d}\left(x_{s}^{d}\right) \mathrm{d} x_{s}^{d}-p_{s}^{d}\left(\hat{x}_{s}^{d}\right) \hat{x}_{s}^{d}+\int_{0}^{\hat{y}_{s}^{d}} p_{s}^{* d}\left(y_{s}^{d}\right) \mathrm{d} y_{s}^{d}-p_{s}^{* d}\left(\hat{y}_{s}^{d}\right) \hat{y}_{s}^{d}\right]+[1- \\
& \alpha(\hat{r})]\left[\int_{0}^{\hat{x}_{s}^{h}} p_{s}^{h}\left(x_{s}^{h}\right) \mathrm{d} x_{s}^{h}-p_{s}^{h}\left(\hat{x}_{s}^{h}\right) \hat{x}_{s}^{h}+\int_{0}^{\hat{y}_{s}^{h}} p_{s}^{* h}\left(y_{s}^{h}\right) \mathrm{d} y_{s}^{h}-p_{s}^{* h}\left(\hat{y}_{s}^{h}\right) \hat{y}_{s}^{h}\right]
\end{aligned}
$$

Under free trade, the Northern country's expected national welfare equals the sum of its expected profit and domestic consumer surplus: $E[\widehat{\mathrm{W}}(\hat{r})]=E[\widehat{\Pi}(\hat{r})]+E[\widehat{\mathrm{CS}}(\hat{r})]$. Same goes for the Southern country's expected welfare: $E\left[\widehat{\mathrm{W}}^{*}(\hat{r})\right]=E\left[\widehat{\Pi}^{*}(\hat{r})\right]+E\left[\widehat{\mathrm{CS}}^{*}(\hat{r})\right]$.

\subsection{Discussion}

Table 1 illustrates the economic impact of each policy instrument. We also study the impact on the Northern country's expected public revenues. ${ }^{15}$

Table 1 - Economic Impact of Each Policy Instrument

\begin{tabular}{|l|l|l|l|l|l|l|}
\hline Instrument & $r$ & $E(\Pi)$ & $E\left(\Pi^{*}\right)$ & $E(\mathrm{CS})$ & $E\left(\mathrm{CS}^{*}\right)$ & $E(\mathrm{PR})$ \\
\hline
\end{tabular}

${ }^{15} E[\widehat{\mathrm{PR}}(\hat{r})]=\left\{\begin{array}{c}t\left\{\alpha(\hat{r}) \hat{y}_{n}^{d}+[1-\alpha(\hat{r})] \hat{y}_{n}^{h}\right\}>0, \text { with the import tariff } \\ -s\left\{\alpha(\hat{r})\left(\hat{x}_{n}^{d}+\hat{x}_{s}^{d}\right)+[1-\alpha(\hat{r})]\left(\hat{x}_{n}^{h}+\hat{x}_{s}^{h}\right)\right\}<0, \text { with the production subsidy } \\ -\sigma \hat{r}<0, \text { with the Research and Development subsidy }\end{array}\right.$ 


\begin{tabular}{|l|c|c|c|c|c|c|}
\hline Import Tariff & + & + & - & $+/-$ & $+/-$ & + \\
\hline Production Subsidy & + & + & - & + & + & - \\
\hline R\&D Subsidy & + & + & - & $+/-$ & $+/-$ & - \\
\hline Quality Standard & + & $+/-$ & - & $+/-$ & $+/-$ & 0 \\
\hline Minimum-Price & + & + & - & $+/-$ & $+/-$ & 0 \\
\hline Import Quota & $+/-$ & $+/-$ & $+/-$ & $+/-$ & $+/-$ & 0 \\
\hline
\end{tabular}

Source: authors.

Each policy instrument increases the Northern firm's R\&D expenditures except for the quality standard and the import quota. A government that aims to enhance non-price competitiveness by encouraging product R\&D investment should implement one of these policy instruments. Furthermore, the Northern (Southern) firm's expected profit always increases (decreases) with each policy instrument. This result relates to the "profit-shifting" mentioned in the economic literature. Nevertheless, policy instruments may have opposite impacts on expected consumer surplus and public revenues. The Northern country's expected public revenues increase with the import tariff, decrease with the production subsidy and the R\&D subsidy, and level off with the quality standard and the minimum-price.

Let us study the impact on the Northern country's consumer surplus. It increases with the production subsidy because it has a direct impact by reducing the levels of price. The R\&D subsidy has an indirect impact by increasing the probability of $R \& D$ success. But the impact on the expected consumer surplus may be negative if the sensitivity $\eta$ is low. The impact of the import tariff and the minimumprice may be either positive or negative because of a direct negative impact due to the increase of levels of price and an indirect positive impact due to the increase of the probability of R\&D success. The impact of each policy instrument on the Southern country's consumer surplus is the same.

The economic impact of the quality standard is uncertain. The effect on the Northern firm's expected profit is unknown because the effect is positive with a successful R\&D and negative with an unsuccessful R\&D. The effect on the Northern consumer surplus is uncertain because it increases the Northern firm's R\&D investment but it reduces the demand on the Northern market. The economic impact of a quota is also ambiguous because it reduces the competition from the Southern country but it either increases or reduces the Northern firm's R\&D investment. Then, the effect on each expected profit and consumer surplus is uncertain.

Appendix B illustrates the evolution of the Northern country's expected consumer surplus when the Northern government implements an import tariff such as $t=1$, a quality standard, a relatively binding minimum-price such as $p_{\min }=p^{* d}+z$, a very binding minimum-price such as $p_{\min }=p^{* h}+$ $z$, where $z$ is a positive constant, and a prohibitive import quota. The effect of the tariff is often negative. Nevertheless, we find a case in which the expected consumer surplus increases with the tariff. The effect is positive for $\eta \geq 2.3$ when $b=3$. We also find a case in which the quality standard increases the expected consumer surplus for $\eta \geq 1.25$ when $b=3$. Finally, the relatively binding minimum-price increases the expected consumer surplus for $\eta \geq 1.5$ when $b=2$, and $\eta \geq 1.75$ when $b=3$, while the very binding minimum-price increases it for $\eta \geq 1.25$ when $b=2$. Under these cases, the indirect positive impact via the probability of R\&D success is stronger than the direct negative impact. Such a result can be offset against traditional results that mention a negative impact of "at-the border" policy instruments on the consumer surplus. The condition is that consumers have a high sensitivity on their preference for quality. Unlike an import tariff or a quality standard, we do 
not find any case in which a very binding quota increases the Northern country's expected consumer surplus by using numerical simulations.

\subsection{Optimal Policy Instruments under Numerical Simulations}

According to the economic impact of each policy instrument, we have to verify whether or not the Northern country's government is encouraged to implement it. Let us study the impact on the Northern country's expected national welfare. We can also compare each instrument. Appendix C illustrates the optimal level of each instrument and the expected national welfare as compared to free trade. The results are obtained under numerical simulations because analytical demonstrations seem too complex.

- The Northern country's government is encouraged to implement an import tariff and a production subsidy. The tariff seems to be the favorite policy instrument because: (i) it increases the Northern firm's profit via the "profit-shifting"; (ii) it also increases its R\&D investment; (iii) it involves further public revenues for the government; (iv) it may increase the expected consumer surplus when their preference for quality is high, and the negative effect is low, otherwise.

- The positive impact of the production subsidy is lower even if it is the favorite policy instrument for the Northern consumer since it reduces prices and increases the probability of vertical differentiation. The reason is that it involves public expenditures, especially if the R\&D is successful.

- The quality standard reduces the Northern country's expected national welfare under each case illustrated in Appendix B. The effect may be positive with higher values for $\eta$. But the quality standard is never the Northern government's favorite policy instrument. The Northern government has a preference for the import tariff because we consider that the quality standard does not yield public revenues. Furthermore, the effect on the domestic consumer surplus is often negative.

- Under four cases, the Northern country's government is not encouraged to implement the minimum-price because the optimal level equals the free trade level of price when the R\&D is successful. Then, the expected Northern welfare is the same as under free trade. This welfare increases with the minimum-price, otherwise. The main difference with the import tariff is that we do not consider that the minimum-price influences public revenues.

- Under two cases, the optimal R\&D subsidy is negative. Then, the Northern country's government is encouraged to tax the Northern firm's R\&D expenditure. Note that the effects on the expected welfare are low because it only directly influences the probability of R\&D success.

- The quota increases the Northern country's expected national welfare under seven cases. In these cases, the optimal quota is a prohibitive quota such as the Northern firm benefits from a monopoly on its domestic market. But the quota reduces the expected national welfare under five cases. In these cases, the Northern government is encouraged to remain under free trade.

The results show that the import tariff seems to be the favorite policy instrument for the Northern government. The Northern government can increase its domestic firm's expected profit, its consumer surplus and public revenues at the same time, only by implementing an import tariff. However, there is a limit. Tariffs represent traditional forms of trade policy. Currently, governments reduce their tariff rates by implementing free trade agreements and use modern forms of protectionism like subsidies, quality standards and minimum-prices. Furthermore, according to the WTO, tariffs are bound and cannot be increased above a certain level. Nevertheless, as we said in the introduction, the level of 
the European Union's ad-valorem import tariff is high in the automobile industry. It may legitimize our results.

\section{Concluding Remarks}

In this paper, we establish a theoretical model of international trade in a two-country duopoly with a Northern and Southern firm to examine the impact of several trade policy instruments on product $R \& D$ investment and welfare. The Southern firm is considered to have a competitive advantage due to lower production costs, encouraging the Northern competitor to invest in quality improvement. Unlike related studies but just as relevant and realistic, we suppose that the outcome of this investment is uncertain: there is a given probability for the Northern firm's product R\&D to be successful. The Northern country's government is the only one policy active, having the choice between several policy instruments: an import tariff, a production subsidy, an R\&D subsidy, a minimum quality standard, a minimum-price and an import quota. Firms compete in prices on both markets.

Through our three-stage game, we show that each policy instrument increases the Northern firm's product R\&D investment except for a relatively binding import quota. Therefore, if the Northern country's government's only aim is to enhance non-price competitiveness by encouraging product $R \& D$ investment, we provide evidence in favor of implementing these policy instruments. However, it is also argued that the effect of some of these instruments may hinder consumer surplus, public revenues and welfare. Their implementation might not therefore be socially optimal. This result is backed by numerical simulations allowing for a change in the levels of parameters. Based on these simulations and a comparison of the impact of these instruments, it appears that the Northern country's government would favor the implementation of an import tariff. By this means, the domestic expected profit, consumer surplus and public revenues could increase. Nevertheless, the real implications of this result are limited, as the ongoing trend in the international arena is towards the reduction of this trade barrier.

The analysis we conducted is relevant to international trade between developed and developing countries, high and low cost firms, in which the latter do not necessarily have the capacities to undergo quality improvement and finance product R\&D activities. We believe to have contributed in the existing literature by building such a framework, including uncertainty in it and analyzing the impact of a relatively wide panel of instruments. The positive impact of several policy instruments on the R\&D investment in our theoretical paper has been illustrated in empirical studies. The empirical economic literature has focused on the impact of "behind-the-border" policy instruments on R\&D expenditures by differentiating direct supports (subsidies) and tax cuts. A positive relationship is illustrated for US firms (Mansfield, 1986; Berger, 1993; Hall, 1993), Canadian firms (Mansfield and Switzer, 1985; Bernstein, 1986), Swedish firms (Mansfield, 1986) and nine OECD countries (Bloom et al., 2002). Nevertheless, we realize that there is no empirical evidence about the negative impact of a relatively binding import quota in our paper.

An extension to our study would be to consider competition in quantities instead of prices and see how the mode of competition changes our results. Changing the setting of the model by analyzing trade between identical firms in a North-North or South-South duopoly is also possible to have important implications and constitute future research topics. Another possible extension would be to 
consider individual preferences for quality for each consumer. Finally, we could consider that the Southern government becomes policy active by implementing retaliations.

\section{Acknowledgments}

The authors would like to thank the participants at a LAREFI Seminar in Bordeaux, France, and at the $2^{\text {nd }}$ Workshop on Macroeconomics of Agriculture and Development in Bordeaux. The authors are also grateful for a Research Grant from the French Ministry of Research.

\section{Appendix}

\section{A. Impact of an Import Tariff under General Forms for Demand Functions}

We use general forms for demand functions. Nevertheless, we still consider constant marginal costs and linear forms for total costs. According to First Order Conditions, we have: ${ }^{16} \hat{\pi}_{n}^{h}(t)=\pi_{n}^{h}\left[\hat{p}_{n}^{h}(t)\right]=$ $-x_{n_{p_{n}}}^{h}\left[\hat{p}_{n}^{h}(t)-c^{h}\right]^{2}, \hat{\pi}_{n}^{d}(t)=\pi_{n}^{d}\left[\hat{p}_{n}^{d}(t)\right]=-x_{n_{p_{n}}}^{d}\left[\hat{p}_{n}^{d}(t)-c^{d}(\phi)\right]^{2}$. We have: ${ }^{17}$

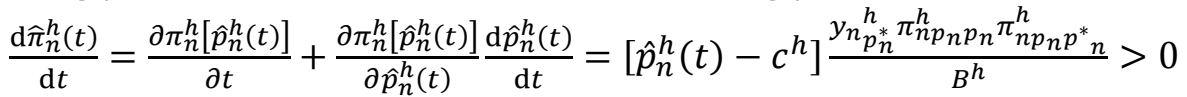

$\frac{\mathrm{d} \hat{\pi}_{n}^{d}(t)}{\mathrm{d} t}=\frac{\partial \pi_{n}^{d}\left[\hat{p}_{n}^{d}(t)\right]}{\partial t}+\frac{\partial \pi_{n}^{d}\left[\hat{p}_{n}^{d}(t)\right]}{\partial \hat{p}_{n}^{d}(t)} \frac{\mathrm{d} \hat{p}_{n}^{d}(t)}{\mathrm{d} t}=\left[\hat{p}_{n}^{d}(t)-c^{d}(\phi)\right] \frac{y_{n_{p_{n}^{*}}}^{d} \pi_{n p_{n} p_{n}}^{d} \pi_{n p_{n} p_{n}^{*}}^{d}}{B^{d}}>0$

The previous expressions are positive. But it seems complex to compare such expressions. We have: $\left|y_{n} \underset{p_{n}^{*}}{d}\right|>\left|y_{n_{p_{n}^{*}}}^{h}\right|$. We also made the assumption that the marginal profit is higher when the R\&D is successful; see Assumption 7. Then: $\left[\hat{p}_{n}^{d}(t)-c^{d}(\phi)\right]>\left[\hat{p}_{n}^{h}(t)-c^{h}\right]$. However, it is complex to compare the two last terms $\pi_{n p_{n} p_{n}}^{d} \pi_{n p_{n} p_{n}^{*}}^{d} / B^{d}$ and $\pi_{n p_{n} p_{n}}^{h} \pi_{n p_{n} p_{n}^{*}}^{h} / B^{h}$, especially under nonlinear forms. First order effects are on $y_{n_{p_{n}^{*}}}^{d}$, then on $\left[\hat{p}_{n}^{d}(t)-c^{d}(\phi)\right]$. The probability that the tariff increases the difference in profit remains high. But we cannot demonstrate that the effect is always positive.

\section{B. Impact of "At-The-Border" Policy Instruments on Expected Consumer Surplus}

\footnotetext{
${ }^{16}$ Subscripts denote partial derivatives.

${ }^{17} B^{h}=\pi_{n p_{n} p_{n}}^{h} \pi_{n p_{n}^{*} p_{n}^{*}}^{* h}-\pi_{n p_{n} p_{n}^{*}}^{h} \pi_{n p_{n}^{*} p_{n}}^{* h} ; B^{d}=\pi_{n p_{n} p_{n}}^{d} \pi_{n p_{n}^{*} p_{n}^{*}}^{* d}-\pi_{n p_{n} p_{n}^{*}}^{d} \pi_{n p_{n}^{*} p_{n}}^{* d}$
} 
Table 2 - Evolution of the Northern Country's Expected Consumer Surplus with an Import Tariff, a Quality Standard, a Minimum-price and an Import Quota

\begin{tabular}{|l|c|c|c|c|c|c|c|c|}
\hline & \multicolumn{2}{|c|}{$\begin{array}{c}\text { Import Tariff such as } \\
t=1\end{array}$} & \multicolumn{2}{c|}{ Quality Standard } & \multicolumn{2}{c|}{$\begin{array}{c}\text { Relatively Binding } \\
\text { Minimum-Price such as } \\
p_{\min }=\hat{p}_{n}^{* d}+z\end{array}$} & \multicolumn{2}{c|}{$\begin{array}{c}\text { Very Binding Minimum- } \\
\text { Price such as } p_{\text {min }}= \\
\hat{p}_{n}^{* h}+z\end{array}$} \\
\hline$\eta$ & $b_{i}=2$ & $b_{i}=3$ & $b_{i}=2$ & $b_{i}=3$ & $b_{i}=2$ & $b_{i}=3$ & $b_{i}=2$ & $b_{i}=3$ \\
\hline 0.25 & -8.21229 & -7.79463 & -130.43874 & -42.577665 & -0.0780794 & -0.0364256 & -2.5257042 & -1.8376590 \\
\hline 0.5 & -8.00433 & -7.70639 & -123.42937 & -39.761767 & -0.1433769 & -0.0732299 & -4.6014483 & -2.4831033 \\
\hline 0.75 & -7.56517 & -7.51798 & -114.43250 & -35.806893 & -0.1773104 & -0.0998316 & -5.9272671 & -3.0294014 \\
\hline 1 & -6.79448 & -7.18616 & -103.77156 & -30.567629 & -0.1641472 & -0.1098467 & -3.9357802 & -2.8019087 \\
\hline 1.25 & -5.55152 & -6.65085 & -91.956658 & -23.864448 & -0.0813091 & -0.0941329 & 4.9719231 & -0.8482512 \\
\hline 1.5 & -3.63511 & -5.82695 & (b) & -15.475250 & 0.1040853 & -0.0393999 & 25.972551 & (c) \\
\hline 1.75 & (a) & -4.59141 & (a) & -5.1243504 & (a) & 0.0740211 & (a) & (c) \\
\hline 2 & (a) & -2.76199 & (a) & 7.5315659 & (a) & 0.2758692 & (a) & (c) \\
\hline 2.25 & (a) & -0.06126 & (a) & 22.920640 & (a) & 0.6122734 & (a) & (c) \\
\hline 2.5 & (a) & 3.946958 & (a) & 41.574760 & (a) & 1.1570145 & (a) & (c) \\
\hline
\end{tabular}

\begin{tabular}{|lc|c|}
\hline & \multicolumn{2}{c}{$\begin{array}{c}\text { Prohibitive Import Quota } \\
q=0\end{array}$} \\
\hline \multicolumn{1}{|c|}{$\eta$} & $b_{i}=2$ & $b_{i}=3$ \\
\hline 0.25 & -109.31687 & -50.643907 \\
\hline 0.5 & -105.74391 & -49.701643 \\
\hline 0.75 & -99.622142 & -48.052939 \\
\hline 1 & -90.910905 & -45.681178 \\
\hline 1.25 & -79.584335 & -42.584499 \\
\hline 1.5 & -65.667615 & -38.790345 \\
\hline 1.75 & (a) & -34.380851 \\
\hline 2 & (a) & -29.538119 \\
\hline 2.25 & (a) & -24.627170 \\
\hline 2.5 & (a) & -20.353072 \\
\hline
\end{tabular}

Source: authors. Note: We set: $c^{d}(\phi)=c^{h}+\phi, a_{n}=40, a_{s}=30, c^{h}=6, c^{*}=3, \phi=0.2, g=g^{*}=1, F=$ $F^{*}=0, z=0.1$. (a) The condition $b>(1+\phi \eta) /(1-\phi \eta)$ no longer holds. (b) The level of R\&D is greater than one. (c) The Southern firm's exports are negative under a successful R\&D.

\section{Welfare Analysis}

Table 3 - Optimal Policy Instruments and Evolution of the Northern Country's Expected National Welfare

\begin{tabular}{|c|c|c|c|c|c|}
\hline & & & Policy Instrument & Optimal Instrument & $\Delta E(\mathrm{~W})$ \\
\hline \multirow[t]{4}{*}{$\phi=0.2$} & \multirow[t]{3}{*}{$b_{n}=b_{s}=2$} & $\eta=0.5$ & $\begin{array}{l}\text { Import Tariff } \\
\text { Production Subsidy } \\
\text { R\&D Subsidy } \\
\text { Quality Standard } \\
\text { Minimum-Price } \\
\text { Import Quota }\end{array}$ & $\begin{array}{c}16.5508033 \\
3.22254028 \\
18.4727963 \\
- \\
16.2666667 \\
0\end{array}$ & $\begin{array}{c}183.823613 \\
7.78716801 \\
0.01100592 \\
-211.313788 \\
1.1875101 \\
85.1563207\end{array}$ \\
\hline & & $\eta=1$ & $\begin{array}{l}\text { Import Tariff } \\
\text { Production Subsidy } \\
\text { R\&D Subsidy } \\
\text { Quality Standard } \\
\text { Minimum-Price } \\
\text { Import Quota } \\
\end{array}$ & $\begin{array}{c}16.9565435 \\
4.00647595 \\
49.946966 \\
- \\
16.2667 \\
0 \\
\end{array}$ & $\begin{array}{l}200.726885 \\
11.4775243 \\
0.53559784 \\
-98.1804461 \\
23.4199971 \\
109.717667 \\
\end{array}$ \\
\hline & & $\eta=1.5$ & $\begin{array}{l}\text { Import Tariff } \\
\text { Production Subsidy } \\
\text { R\&D Subsidy } \\
\text { Quality Standard } \\
\text { Minimum-Price } \\
\text { Import Quota } \\
\end{array}$ & $\begin{array}{c}14.9758 \\
6.08087264 \\
70.417448 \\
\text { (a) } \\
18.9758242 \\
0 \\
\end{array}$ & $\begin{array}{c}253.037868 \\
23.6015963 \\
3.77024901 \\
\text { (a) } \\
204.613391 \\
157.365722 \\
\end{array}$ \\
\hline & $b_{n}=b_{s}=3$ & $\eta=0.5$ & $\begin{array}{l}\text { Import Tariff } \\
\text { Production Subsidy } \\
\text { R\&D Subsidy } \\
\text { Quality Standard }\end{array}$ & $\begin{array}{c}6.66184031 \\
2.48623055 \\
10.5534091 \\
-\end{array}$ & $\begin{array}{l}47.8342226 \\
6.96309294 \\
0.00081367 \\
-111.105712\end{array}$ \\
\hline
\end{tabular}




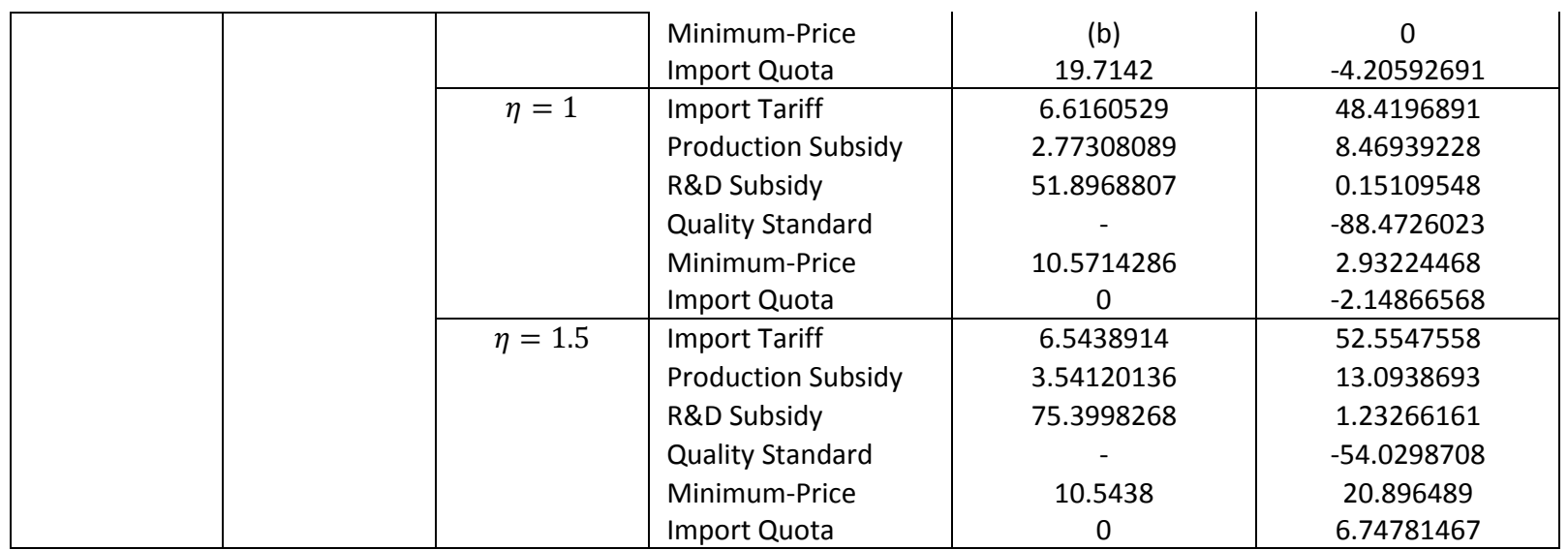

Source: authors.

Note: We set: $c^{d}(\phi)=c^{h}+\phi, a_{n}=40, a_{s}=30, c^{h}=6, c^{*}=3, g=g^{*}=1, F=F^{*}=0$. (a) The level of R\&D is greater than one. (b) The optimal minimum-price equals to the foreign firm's price under free trade when the R\&D is successful. Then, the domestic welfare does not vary as compared to free trade.

Table 3 (continued) - Optimal Policy Instruments and Evolution of the Northern Country's Expected National Welfare

\begin{tabular}{|c|c|c|c|c|c|}
\hline & & & Policy Instrument & Optimal Instrument & $\Delta E(\mathrm{~W})$ \\
\hline \multirow[t]{5}{*}{$\phi=0.1$} & \multirow[t]{3}{*}{$b_{n}=b_{s}=2$} & $\eta=0.5$ & $\begin{array}{l}\text { Import Tariff } \\
\text { Production Subsidy } \\
\text { R\&D Subsidy } \\
\text { Quality Standard } \\
\text { Minimum-Price } \\
\text { Import Quota }\end{array}$ & $\begin{array}{c}16.5512526 \\
3.08585143 \\
-1.50253967 \\
- \\
\text { (b) } \\
0\end{array}$ & $\begin{array}{c}182.0127 \\
7.21336599 \\
1.4456 \mathrm{E}-05 \\
-252.250962 \\
0 \\
79.8616143 \\
\end{array}$ \\
\hline & & $\eta=1$ & $\begin{array}{l}\text { Import Tariff } \\
\text { Production Subsidy } \\
\text { R\&D Subsidy } \\
\text { Quality Standard } \\
\text { Minimum-Price } \\
\text { Import Quota }\end{array}$ & $\begin{array}{c}16.5559191 \\
3.23209595 \\
21.1926214 \\
- \\
16.2666667 \\
0\end{array}$ & $\begin{array}{l}183.987986 \\
7.83206911 \\
0.01556657 \\
-209.067972 \\
1.29264868 \\
85.4552477 \\
\end{array}$ \\
\hline & & $\eta=1.5$ & $\begin{array}{l}\text { Import Tariff } \\
\text { Production Subsidy } \\
\text { R\&D Subsidy } \\
\text { Quality Standard } \\
\text { Minimum-Price } \\
\text { Import Quota } \\
\end{array}$ & $\begin{array}{c}16.6589619 \\
3.5269523 \\
37.6040891 \\
- \\
23.8968944 \\
0 \\
\end{array}$ & $\begin{array}{c}189.45532 \\
9.15483585 \\
0.14054856 \\
-157.233862 \\
74.3164759 \\
95.4051722 \\
\end{array}$ \\
\hline & \multirow[t]{2}{*}{$b_{n}=b_{s}=3$} & $\eta=0.5$ & $\begin{array}{l}\text { Import Tariff } \\
\text { Production Subsidy } \\
\text { R\&D Subsidy } \\
\text { Quality Standard } \\
\text { Minimum-Price } \\
\text { Import Quota }\end{array}$ & $\begin{array}{c}6.68469614 \\
2.44161052 \\
-17.1143338 \\
- \\
\text { (b) } \\
19.7142\end{array}$ & $\begin{array}{c}47.9021165 \\
6.74865203 \\
0.00039848 \\
-118.417947 \\
0 \\
-4.34909786 \\
\end{array}$ \\
\hline & & $\eta=1$ & $\begin{array}{l}\text { Import Tariff } \\
\text { Production Subsidy }\end{array}$ & $\begin{array}{c}6.6619414 \\
2.49138048\end{array}$ & $\begin{array}{l}47.8489397 \\
6.99199091\end{array}$ \\
\hline
\end{tabular}




\begin{tabular}{|l|l|l|c|c|}
\hline & & R\&D Subsidy & 16.120011 & 0.00213532 \\
& & & - & -110.449222 \\
& & Quality Standard & (b) & 0 \\
& & Minimum-Price & 19.7142 & -4.19334793 \\
\hline & & Import Quota & 6.63455079 & 47.9540953 \\
& & & 2.59829226 & 7.53834851 \\
& & Import Tariff & 37.4234915 & 0.03524563 \\
& & Production Subsidy & - & -100.295092 \\
& & R\&D Subsidy & 10.5714286 & 0.41408715 \\
& & Quality Standard & 19.7142 & -4.00875094 \\
\hline
\end{tabular}

Source: authors.

Note: We set: $c^{d}(\phi)=c^{h}+\phi, a_{n}=40, a_{s}=30, c^{h}=6, c^{*}=3, g=g^{*}=1, F=F^{*}=0$. (a) The level of R\&D is greater than one. (b) The optimal minimum-price equals the foreign firm's price under free trade when the R\&D is successful. Then, the domestic welfare does not vary as compared to free trade.

\section{References}

Audretsch, D. B., Yamawaki, H., 1988. R\&D rivalry, industrial policy, and U.S.-Japanese trade. Review of Economics and Statistics. 70(3), 438-447.

Berger, P., 1993. Explicit and implicit effects of the R\&D tax credit. Journal of Accounting Research. 31(2), 131-171.

Bernstein, J. I., 1986. The effect of direct and indirect tax incentives on Canadian industrial R\&D expenditures. Canadian Public Policy / Analyse de Politiques. 12(3), 438-448.

Bhagwati, J. N., 1968. More on the equivalence of tariffs and quotas. American Economic Review. 58, 142-146.

Bloom, N., Griffith, R., Van Reenen, J., 2002. Do R\&D tax credits work? Evidence from a panel of countries 1979-1994. Journal of Public Economics. 85(1), 1-31.

Bouët, A., 2001. Research and development, voluntary export restriction and tariffs. European Economic Review. 45(2), 323-336.

Capon, N., Farley, J. U., Lehman, D. R., Hulbert, J. M., 1992. Profiles of product innovators among large U.S. manufacturers. Management Science. 38(2), 157-169.

Chenavaz, R., 2011. Dynamic pricing rule and R\&D. Economics Bulletin. 31(3), 2229-2236.

Cheng, Y.-L., 2014. Vertical product differentiation under demand uncertainty. Economic Modelling. 36, 51-57.

Das, S. P., Donnenfeld, S., 1989. Oligopolistic competition and international trade. Journal of International Economics. 27(3-4), 299-318.

Evenett, S. J., 2013. Protectionism's quiet return. Centre for Economic Policy Research. Global Trade Alert. GTA's Pre-G8 Summit Report. 
Fritsch, M., Meschede, M., 2001. Product innovation, process innovation, and size. Review of Industrial Organization. 19, 335-350.

Gabriele, A., 2002. S\&T policies and technical progress in China's industry. Review of International Political Economy. 9(2), 319-358.

Hall, B. H., 1993. R\&D tax policy during the eighties: success or failure? NBER Working Paper, 4240.

Impullitti, G., 2010. International competition and U.S. R\&D subsidies: a quantitative welfare analysis. International Economic Review. 51(4), 1127-1158.

Ishii, Y., 2014. Quality-price competition and product R\&D investment policies in developing and developed countries. Economic Record. 90(289), 197-206.

Jinji, N. 2003. Strategic policy for product R\&D with symmetric costs. Canadian Journal of Economics. 36(4), 993-1006.

Jinji, N., Toshimitsu, T., 2006. Optimal policy for product R\&D with endogenous quality ordering: asymmetric duopoly. Australian Economic Papers. 45(2), 127-140.

Jinji, N.,Toshimitsu, T., 2013. Strategic R\&D policy in a quality-differentiated industry with three exporting countries. Japan and the World Economy. 28, 132-142.

Klepper, S., 1996. Entry, exit and innovation over the product life cycle. American Economic Review. 86(3), 562-583.

Krishna, K., 1989. Trade restrictions as facilitating practices. Journal of International Economics. 26(34), 251-270.

Krugman, P. R., 1984. Import protection as export promotion: international competition in the presence of oligopoly and economies of scale. In: Kierzkowski, H., 2001 (ed.). Monopolistic Competition and International Trade. Clarendon Press, Oxford. Chapter 11, 180-193.

Landau, R., Rosenberg, N., 1992. Successful commercialization in the chemical process industries. In: Rosenberg, N, Landau, R., Mowery, D., 1992 (ed.). Technology and The Wealth of Nations. Stanford University Press, Stanford. Part 1, Chapter 4, 73-120.

Mansfield, E., Switzer, L, 1985. The effects of R\&D tax credits and allowances in Canada. Research Policy. 14(2), 97-107.

Mansfield, E., 1986. The R\&D tax credit and other technology policy issues. American Economic Review. 76(2), 190-194.

Maskus, K. E., Otsuki, T., Wilson, J. S., 2013. Do foreign product standards matter? Impact on costs for developing country exporters. Asia-Pacific Journal of Accounting and Economics. 20(1), 37-57.

Moraga-Gonzalez, J. L., Viaene, L.-M., 2005. Trade policy and quality leadership in transition economies. European Economic Review. 49, 359-385.

Mussa, M., Rosen, S., 1978. Monopoly and product quality. Journal of Economic Theory. 18(2), 301317.

Nagaoka, S., Walsh, J. P., 2008. The R\&D process in the US and Japan: Major findings from the RIETIGeorgia Tech inventor survey. RIETI Discussion Paper Series. 09-E-010.

Park, J.-H., 2001. Strategic R\&D policy under vertically differentiated oligopoly. Canadian Journal of Economics. 34(4), 967-988.

Reitzes, J. D., 1991. The impact of tariffs and quotas on strategic R\&D behavior. International Economic Review. 32(4), 985-1007.

Scherer, F. M., Ross, D., 1990. Industrial Market Structure and Economic Performance. Houghton Mifflin, Boston.

Schwab, K., 2014. The Global Competitiveness Report 2014-2015: Full Data Edition. World Economic Forum.

Shaked, A., Sutton, J., 1982. Relaxing price competition through product differentiation. The Review of Economic Studies. 49(1), 3-13.

Spencer, B. J., Brander, J. A., 1983. International R\&D rivalry and industrial strategy. Review of Economic Studies. 50, 702-722. 
Sutton, J., 1997. One smart agent. The RAND Journal of Economics. 28(4), 605-628.

Symeonidis, G., 2003. Comparing Cournot and Bertrand equilibria in a differentiated duopoly with product R\&D. International Journal of Industrial Organization. 21(1), 39-55.

Toshimitsu, T., 2003. Optimal R\&D policy and endogenous quality choice. International Journal of Industrial Organization. 21(8), 1159-1178.

Utterback, J., Abernathy, W., 1975. A dynamic model of process and product innovation. Omega, The International Journal of Management Science. 3(6), 639-656.

Zhou, D., Spencer, B. J., Vertinsky, I., 2002. Strategic trade policy with endogenous choice of quality and asymmetric costs. Journal of International Economics. 56(1), 205-232. 


\section{RECENT LAREFI Working PAPERS}

\section{For earlier LAREFI Working Papers, please go to http://lare-efi.u-bordeaux4.fr}

\section{All Discussion Papers can be downloaded free of charge}

CR16-EFI01 Raffestin, L., "Foreign exchange investment rules and endogenous currency crashes"

CR15-EFI05 Berthoumieu,J., "Technology Diffusion via Patent Collaborations : The Case of European Integration"

CR15-EFI04 Bouet, A. and A-G. Vaubourg, "Financial Constraints and International Trade with Endogenous Mode of Competition"

CR15-EFI03 Lahet, D. and A-G. Vaubourg, "Banks' shareholding in multilateral trading facilities : A two-sided market perspective"

CR15-EFI02 Berthoumieu, J., "Policy Instruments, Patents and International Technology Diffusion in a North-South Duopoly"

CR15-EFI01 Dupuy, L., "International trade and structural change : a dynamic model of weak sustainability"

CR14-EFI06 Humblot, T., "Basel III and SMEs' access to bank credit : An empirical assessment"

CR14-EFI05 Nicet-Chenaf, D., Rougier, E., "Source and host country volatility and FDI : A gravity analysis of European investment to Middle East and North Africa"

CR14-EFI/04 Djigbenou, M-L., "Determinants of Global Liquidity Dynamics:a FAVAR approach"

CR14-EFI/03 Vaubourg, A-G., "Finance and international trade : A review of the literature"

CR14-EFI/02 Sangaré, I., "Chocs extérieurs et régimes monétaires en Asie du Sud-Est : une analyse DSGE"

CR14-EFI/01 Lacoue-Labarthe, D., "In Search of the Banking Regulator amid U.S. Financial Reforms of the 1930s" 